\title{
The NEBIE plot network: Highlights of long-term scientific studies
}

by F. Wayne Bell ${ }^{1 *}$, Jennifer Dacosta ${ }^{1}$, Steven G. Newmaster ${ }^{2}$, Azim Mallik ${ }^{3}$, Shelley Hunt ${ }^{4}$, Madhur Anand ${ }^{4}$, Jose Maloles ${ }^{2}$, Changhui Peng ${ }^{5}$, John Parton ${ }^{6}$, John McLaughlin ${ }^{7}$, John Winters ${ }^{1}$, Monique Wester ${ }^{1}$ and Margo Shaw ${ }^{8}$

\begin{abstract}
The NEBIE plot network is a stand-scale, multi-agency research project designed to compare the ecological effects of a range of silvicultural treatments in northern temperate and boreal forest regions of Ontario, Canada. While research on silviculture intensities has been previously conducted, the NEBIE plot network is at a larger scale, and covers a wider range of intensities in a variety of northern temperate and boreal forest types. Details about experimental design, treatment designs and research sites, are presented in a companion paper which is published in this edition of The Forestry Chronicle. The operational scale of treatment plots allow for assessment of a variety of forest values. We used a criteria and indicator approach to organize long-term research studies on the network sites, with the goal of providing scientific findings that would inform forest policy. Pre-treatment, and 2-, 5-, and 10-year post-harvesting data have been collected. These initial data add to existing information on the effects of intensification of silviculture on biological diversity, forest productivity, ecosystem health and vitality, soil and water resources, contribution of enhanced forest management global carbon cycles, and long-term multiple socio-economic benefits of northern forests.
\end{abstract}

Keywords: ecosystem services, forest research, silviculture, sustainable forest management

\section{RÉSUMÉ}

Le réseau de placettes NEBIE est un projet de recherche à léchelle du peuplement regroupant plusieurs organismes et destiné à comparer les effets écologiques d'une gamme d'interventions sylvicoles dans les régions tempérée et boréale en Ontario au Canada. Même s'il y a déjà eu des travaux de recherche sur l'intensification de la sylviculture, le réseau de placettes NEBIE se situe à une bien plus grande échelle et se prête ainsi à expérimenter une plus vaste gamme d'intensités dans une variété de conditions dans les forêts tempérées et boréales. On trouvera plus de renseignements sur le plan expérimental, les traitements et les sites expérimentaux dans un autre article de ce numéro du The Forestry Chronicle. Le fait qu’on dispose de placettes à léchelle opérationnelle permet dévaluer une variété de valeurs forestières en même temps. Nous avons adopté une approche par critères et indicateurs pour disposer les sites expérimentaux à long terme sur les différentes stations du réseau en vue dobtenir des résultats scientifiques qui puissent apporter des éclairages pour guider la politique forestière. On dispose maintenant de mesures prises avant les traitements puis 2,5 et 10 ans après la récolte. Ces données de départ sajoutent à la documentation portant sur les effets de la sylviculture intensive sur la biodiversité, la productivité forestière, la santé et la vitalité des écosystèmes, les sols et les ressources en eau, la contribution de l'aménagement bonifié sur les cycles planétaires du carbone et les nombreux bienfaits socioéconomiques à long terme liés aux forêts nordiques.

Mots-clés : écoservices, recherche forestière, aménagement forestier durable

\footnotetext{
${ }^{1}$ Ontario Forest Research Institute, Ontario Ministry of Natural Resources, Sault Sainte Marie, Ontario; ${ }^{\star}$ corresponding author: wayne.bell@ontario.ca

${ }^{2}$ Centre for Biodiversity Genomics, Biodiversity Institute of Ontario (BIO), University of Guelph, Guelph, Ontario, Canada. N1G 2W1

${ }^{3}$ Department of Biology, Lakehead University, Thunder Bay, Ontario, Canada P7B 5E1

${ }^{4}$ School of Environmental Sciences, University of Guelph, 50 Stone Road East, Guelph, Ontario, Canada N1G 2W1

${ }^{5}$ Department of Biology Sciences, University of Quebec at Montreal (UQAM), Montréal, Quebec, Canada, H3C 3P8

${ }^{6}$ Science and Research Branch, Ontario Ministry of Natural Resources, Timmins, Ontario, Canada, P0N 1H0

${ }^{7}$ BioForest, Sault Ste. Marie, Ontario, Canada, P6B 5P3

${ }^{8}$ Manitoba Environmental Industries Association (MEIA), 100-62 Albert St., Winnipeg, Manitoba, Canada, R3B 1E9
} 


\section{Introduction}

In Ontario, Canada, the intensification of silviculture is being considered to enhance fibre production (see Bell et al. 2008, Bruemmer 2008) and harvesting of wood biomass is being considered in the context of bioenergy (Mabee et al. 2011, Puddister et al. 2011). These and other changes require new information that can be used to ensure that these modified practices fit within the context of sustainable development.

Since the early 1990s, sustainable development has been embraced by the Ontario Ministry of Natural Resources and Forestry (OMNRF) as the cornerstone of its strategic directions for forest management (OMNR 2011). The overall context for forest management in Ontario is outlined in the Policy Framework for Sustainable Forestry (OMNR 1994) and the Crown Forest Sustainability Act (CFSA; Statutes of Ontario 1994). The stated goal for Ontario's forest is "to ensure the long-term health of our forest ecosystems for the benefit of the local and global environments, while enabling present and future generations to meet their material and social needs." The CFSA documents that "the long-term health and vigour of Crown forest should be provided for by using forest practices that, within the limits of silvicultural requirements, emulate natural disturbances and landscape patterns while minimizing adverse effects on plant life, animal life, water, soil, air and social and economic values, including recreational values and heritage values." Incorporating intensive silviculture into an ecosystem management framework involves additional evaluation of social, economic, and landscape-scale ecological concerns. In order to facilitate such an analysis, OMNRF and research partners established the NEBIE plot network (Bell et al. 2017). Many long-term interdisciplinary research studies are embedded within the NEBIE experimental design framework. The purpose of this paper is to give a brief overview of the studies along with preliminary results. This was done within the context of the Montreal Process criteria (Montreal Process Working Group 2009).

\section{Criteria and indicators}

Many countries, including Canada, have made a commitment to engage in sustainable forest management (UNCED 1992). These countries report on and assess progress towards that goal using a criteria and indicator approach (USDA 2011, OMNR 2012, DEPI 2014). Criteria and indicators provide a science-based framework to define and measure progress towards sustainable forest management. Criteria such as those adopted by the Montreal Process member countries represent forest values that are important to enhance or sustain, while the indicators identify scientific factors that can be used to assess forests and measure progress over time (Montreal Process Working Group 2009).

Criteria and indicators, such as those relating to biodiversity, are commonly linked to pressures, states, benefits or responses (Bell et al. 2014). Pressures are the threats to an indicator such as biodiversity or the forces or actions that are causing conditions to change. State is the current status, or condition, of abiotic (e.g., water, air and soil) or biotic features (e.g., genetic diversity). Benefits describe the various services that are provided by biodiversity to humans and ecosystems (see MEA 2005, Malouin et al. 2016). Responses are policies or actions to address changes in pressures, state and benefits to prevent or reduce negative effects on forest ecosystems. For example, a policy decision to enhance fibre production through silviculture (a response) should lead to increased fibre production (a benefit), but also increase the total amount of disturbance on a landscape (a potential pressure), which may reduce biodiversity (a state change). Thus, it is important to monitor multiple criteria and indicators when making a change in a policy.

\section{NEBIE plot network}

NEBIE includes eight independent randomized complete block experiments (sites), each designed to test a range of silvicultural intensities. Six of the eight sites were fully implemented (Bell et al. 2017). The fully implemented NEBIE sites are located across a broad climatic gradient in several forest types: boreal conifer (Sioux Lookout), boreal mixedwood (Dryden, Kapuskasing, and Timmins), northern temperate mixedwood (Petawawa), and northern temperate hardwood (North Bay). The Wawa and Thunder Bay sites were only partially implemented due to economic reasons. NEBIE spans $45^{\circ} 58^{\prime} \mathrm{N}$ to $50^{\circ} 0^{\prime} \mathrm{N}$ and $77^{\circ} 26^{\prime} \mathrm{W}$ to $92^{\circ} 46^{\prime} \mathrm{W}$ within a geographic area measuring $300 \mathrm{~km}$ north-south and $1100 \mathrm{~km}$ east-west. Across the area, average daily temperatures range from 0.7 to $4.3^{\circ} \mathrm{C}$, extreme annual minimum temperatures range from -40.0 to $-46.7^{\circ} \mathrm{C}$, growing degree days $>5^{\circ} \mathrm{C}$ vary from 1370 to 1779 , annual rainfall is 517.2 to $774.6 \mathrm{~mm}$, and total precipitation ranges between 705 and $1008 \mathrm{~mm}$. Soils vary among sites with depths ranging from 15 to $>120 \mathrm{~cm}$, organic matter depth from 1.6 to $7.4 \mathrm{~cm}$, and soil moisture from moderately dry to very moist. Dominant soil textures are sandy at the Sioux Lookout site; coarse loamy at the Dryden, Petawawa, and North Bay sites; clayey at the Kapuskasing site; and silty at the Timmins site.

Plots or experimental units (EUs), approximately $100 \mathrm{x}$ $200 \mathrm{~m}$ ( $2 \mathrm{ha})$, were established to ensure that treatments would be applied in a semi-operational manner. Treatments were initially replicated four times at each site; however, one of the four temperate hardwood blocks was not harvested as planned, resulting in only three replications in this forest type. The design resulted in 115 experimental units (6 sites $\mathrm{x} 5$ treatments x 4 blocks; except North Bay which has three blocks). Further details regarding the experimental design and sites descriptions are provided in Bell et al. (2017).

For each site, silvicultural strategies thought to have a high probability of leading to economically viable management outcomes were designed with consideration for forest composition and soils. Treatments were randomly assigned to plots. Guidelines for emulating natural disturbance patterns (OMNR 2001), i.e., a minimum of 25 stems ha $^{-1}$ left unharvested, were applied at all but the boreal conifer site. The clearcut and seed tree systems were applied to boreal conifer and boreal mixedwoods, respectively. The shelterwood system (see Smith et al. 1997) was applied to northern temperate hardwood and northern temperate mixedwood forests. Plots of unharvested mature forest, which represent the pre-harvested stands, were randomly selected and now act as untreated controls. Further details regarding treatment designs are also provided in Bell et al. (2017). 


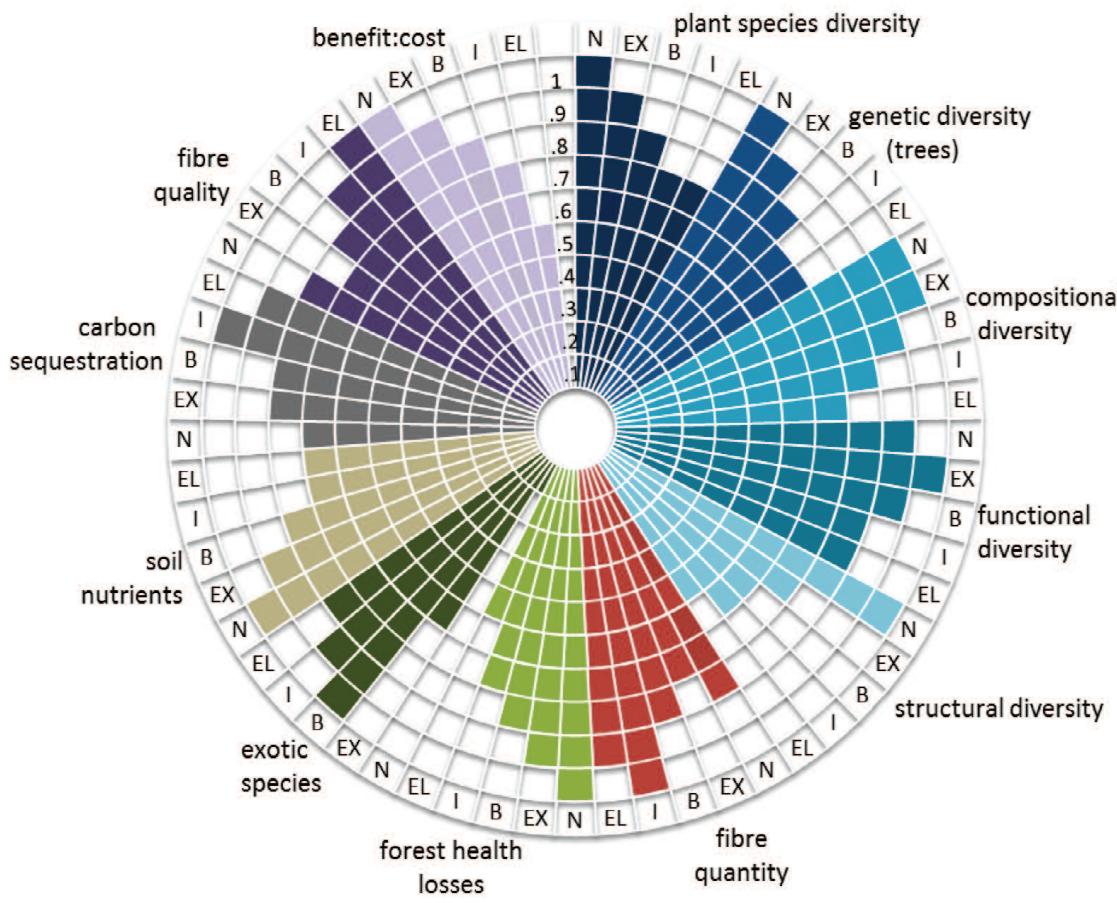

Conservation of Biological Diversity

Maintenance of Productive Capacity of Forest Ecosystems

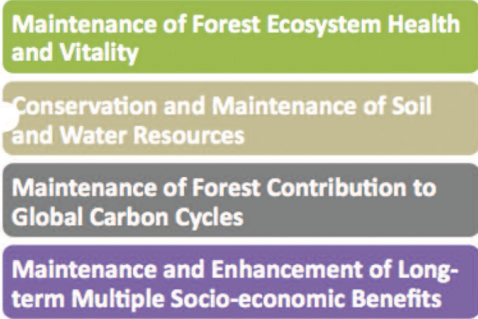

Fig. 1. Theoretical effects lat 50 years post-harvesting) of silvicultural intensities ( $\mathrm{N}$ - natural, Ex - extensive, B - basic, I - intensive, EL - elite] on the conservation of biological diversity, maintenance of productive capacity of forest ecosystems, maintenance of forest ecosystem health and vitality, conservation and maintenance of soil and water resources, maintenance of forest contribution to global carbon cycles, and maintenance and enhancement of long-term multiple socio-economic benefits for forest stands in the NEBIE plot network. Each group is colour coded to correspond with the Montreal process criteria in legend.

\section{Long-term NEBIE Research Studies}

When applying silviculture intensities, forest managers are making trade-offs between treatment costs and increases in fibre production. We structured the research studies in the plot network based on a criteria and indicator approach to enable monitoring of multiple aspects that contribute to sustainable forest management. This enables the use of multivariate trade-off analyses. For example, it is possible to use diagrams to compare treatment responses with respect to biological diversity, productivity, soils, economics, and other variables.

The criteria used to assess sustainability and what is being monitored to provide supporting information are:

- conservation of biological diversity: assessing structural diversity, compositional diversity, and functional diversity of plant species, and genetic diversity of tree species

- maintenance of productive capacity of forest ecosystems: assessing growth and yield of tree species for fibre quantity

- maintenance of forest ecosystem health and vitality: assessing insect and pathogenic populations and exotic species

- conservation and maintenance of soil and water resources: assessing soil nutrients and moisture
- maintenance of forest contribution to global carbon cycles: assessing carbon sequestration

- maintenance and enhancement of long-term multiple socio-economic benefits: assessing fibre quality and the economics of varying silviculture intensities at landscape scale through benefit: cost ratios

Radar diagrams, figures used to present multivariate information, have been used by Petriccione et al. (2007) to study the structure of hardwood forests, Huber-Sannwald et al. (2012) to study ecosystem services, Thompson et al. (2013) to study forest degradation, and Houdet et al. (2014) to study differences in effects of industrial sectors on various indicators (including biodiversity). Using current knowledge for the full suite of variables being collected in the NEBIE plot network (as outlined in more detail below), we developed a radar diagram illustrating theoretical expected patterns at 50 years post-harvest for these forests (Fig. 1).

The scale ranges from 0.1 to 1.0 , where 1.0 represents the largest observed value. For example, the highest quantity of fibre is expected to be produced in the intensive treatment because of the use of higher stocking, improved stock, density regulation, and vegetation control. The highest plant species richness is expected to occur in the basic treatment because 


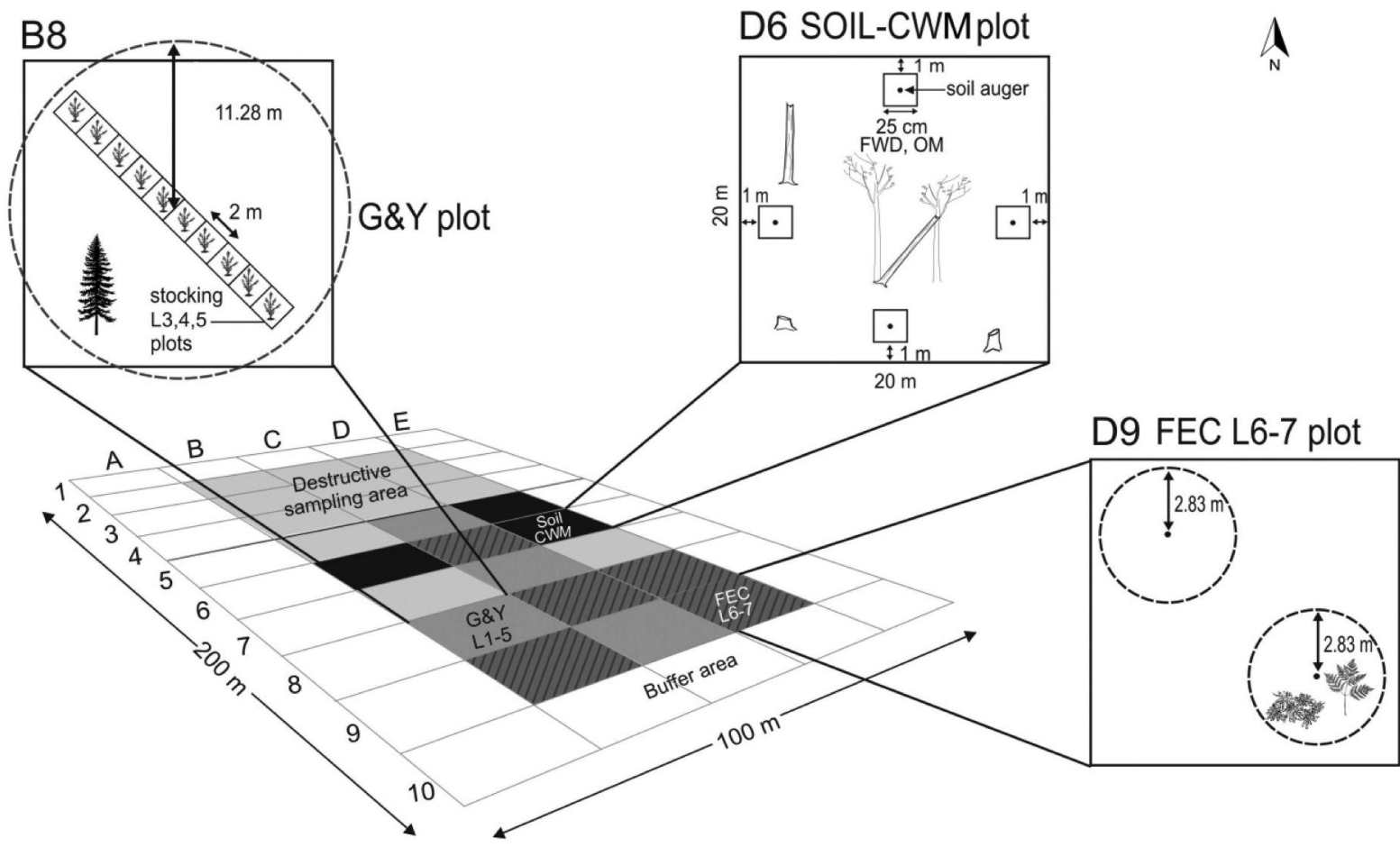

Fig. 2. Standard 2 ha experimental plot used in the NEBIE plot network, showing grid used to identify sub-plots and example of random layout of sampling and monitoring sub-plots (B8 = growth and yield, D6 = soils and coarse woody material, D9 = biodiversity of layers 6 and 7; FEC - forest ecosystem classification].

intermediate disturbances typically support higher species diversity. Conversely, the greatest structural diversity is expected to occur in the unharvested forest, where there is greater accumulation of snags and downed woody material.

\section{Conservation of biological diversity}

Biodiversity conservation research includes studies that focus on compositional (e.g., vegetation and tree genetics), functional (e.g., groups defined by plant traits), and structural (e.g., number of residual trees, tree size, coarse woody material, mineral soil exposure, and rutting) diversity.

\section{Compositional and functional diversity of plant species Species diversity plots}

Floral diversity, the number of species present, is being monitored using permanent sample plots as suggested by Bakker et al. (1996). Presence and abundance (ocular estimate of cover) for all plant species were assessed pre-harvesting at all eight sites and 2-, 5-, and 10-years post-treatment at six sites. Data were collected by sub-plot, individual species, and forest ecosystem classification (FEC) system structural layers (Bell and Newmaster 2002, Newmaster and Bell 2002) and documented using standard species codes (Newmaster et al. 1998).

Categories of plant structural layers (L) were: $\mathrm{L} 1=$ tree in canopy position; L2 = tree in sub-canopy position; L3 = shrub or tree $>2.0$ to $10.0 \mathrm{~m}$ tall; $\mathrm{L} 4=$ shrub or tree 0.5 to $2.0 \mathrm{~m}$ tall; L5 $=$ shrub or tree $<0.5 \mathrm{~m}$ tall; L6 = herb, fern, grass, and sedge; and L7 = moss, lichen, and liverwort (Bell and Newmaster 2002, Newmaster and Bell 2002). Species in L1 and L2 were monitored using the $400 \mathrm{~m}^{2}(20 \times 20 \mathrm{~m})$ growth and yield sub-plots (G\&Y plots in Fig. 2); those in L3 to L5 were monitored using the $4 \mathrm{~m}^{2}(2 \times 2 \mathrm{~m})$ stocking quadrats (G\&Y plots in Fig. 2); and, those in L6 and L7 were monitored using $25 \mathrm{~m}^{2}$ (2.83 $\mathrm{m}$ radius) circular vegetation diversity plots (FEC plots in Fig. 2). In all cases, species cover and layer category were recorded. Height was recorded for L3, L4, and L5 species. A stem count of the L3, L4, and L5 tree species was also recorded.

The number of plant species observed (i.e., richness) was summed for each experimental plot, averaged by site and treatment (Fig. 3). A peak in total species richness evident in the boreal mixedwoods (Dryden, Kapuskasing, Timmins sites) and northern temperate mixedwoods (Petawawa sites) suggests that one or more environmental gradients were interacting with silviculture intensity (Fig. 3). With substantial variation in richness and composition among sites, comparisons of biodiversity intactness (i.e., the deviation in biodiversity from a reference condition) and community composition (Lamb et al. 2009) among silviculture treatments and both the pre-harvesting data and the unharvested forest will be necessary to fully assess the effects of silviculture intensity on biodiversity (Bell et al. 2014, 2016).

\section{Genetic diversity of tree species}

Since trees live for many years and must endure insect infestations, diseases, and climatic extremes, it is important to maintain genetic diversity within each stand to maintain resilience, for example, to ensure that all trees are not equally 


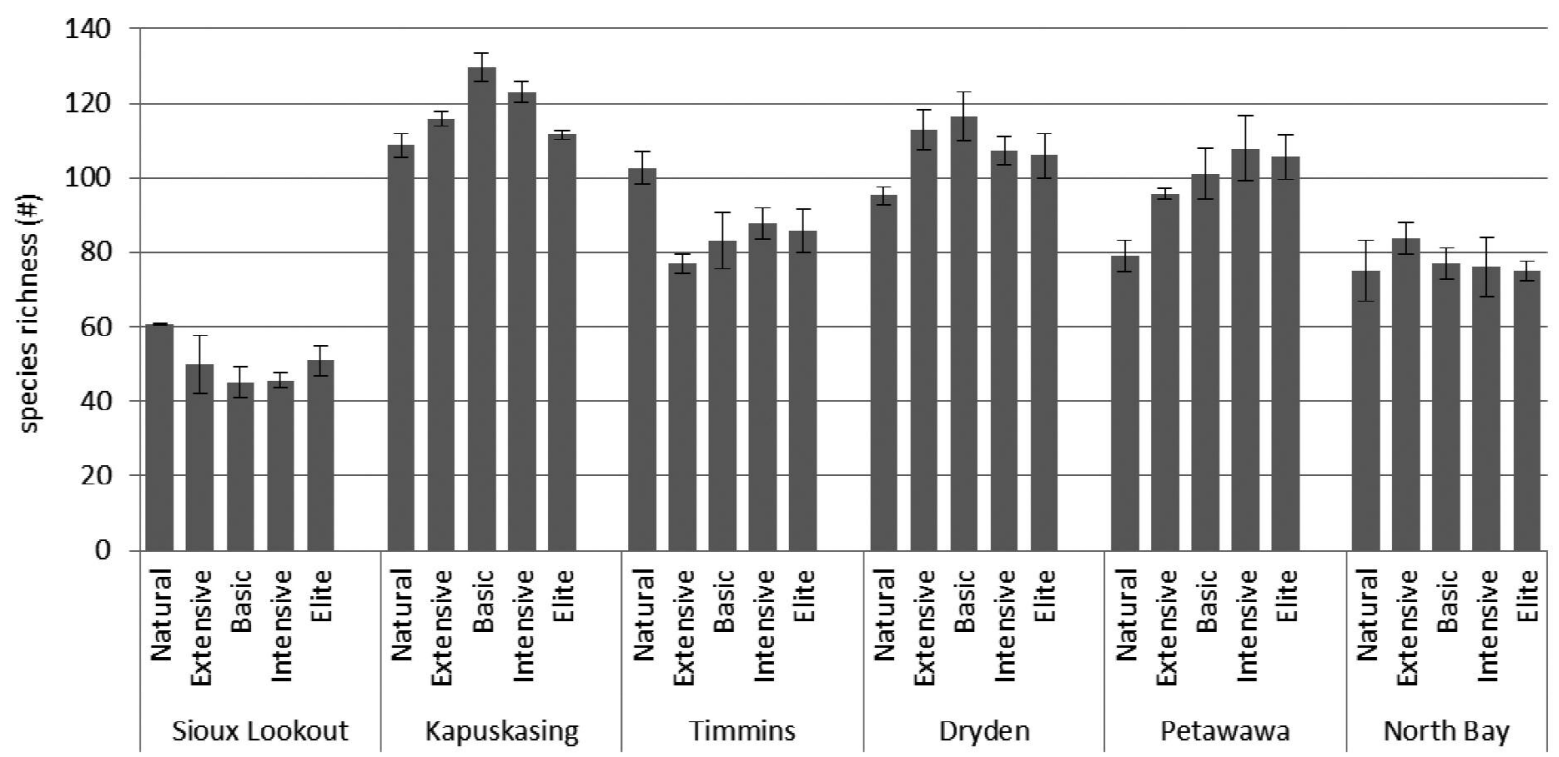

Fig. 3. Total plant species richness 10 years after harvesting by treatment and site for the NEBIE plot network. Error bars represent the standard error among blocks.

susceptible to potential hazards (Smith et al. 1997). We presume genetic diversity to be lowest in the more intensive treatments (Fig. 1), because there is a risk that the combination of harvesting, planting improved stock, and thinning could reduce genetic diversity. Genetic diversity will be examined following establishment of the desired tree species. Parameters to be estimated could include allele richness, frequency distribution and heterozygosity (observed vs. expected), genotype additivity (observed vs. expected), and latent genetic potential (observed vs. expected) (Yang and Yeh 1992, Rajora and Pluhar 2003).

\section{Functional diversity}

Functional diversity describes the range in and value of species traits and their influence on ecosystem functions (Tilman 2001). Species traits can include any morphological, physiological, or phenological feature such as plant height, mode of reproduction, or seed weight (Violle et al. 2007). Each of the vascular plants in the NEBIE plot network was described by several traits, detailed in the literature review module of the Traits of Plants in Canada (TOPIC) database (Aubin et al. 2007, 2012). The traits documented for species in the NEBIE plot network include those in four main categories: (i) morphology such as morphological type, Raunkiaer life form, maximum height, and life cycle; (ii) regeneration and dispersion such as seed dispersal vector, seed weight, and seed persistence; (iii) resource utilization such as water affinity and light requirement; and, (iv) other aspects such as status as native or introduced.

The trait data will be used with plant species abundance information collected pre-harvesting and 2-, 5-, and 10-years post-harvesting to assess changes in functional diversity associated with the intensification of silviculture. There are far too many species in northern temperate and boreal forests to individually study but it is possible to classify them into func- tional response groups (Lavorel et al. 1998, Lavorel and Garnier 2002) and then study the effects of harvesting and silviculture on functional response groups (see Aubin et al. 2009, 2014; Biswas and Mallik 2010; Wang and Chen 2010, Pidgen and Mallik 2013, Bell 2015).

\section{Structural diversity}

Whether forests provide habitat for a diversity of flora and fauna depends, at least in part, on stand structural characteristics (Lindenmayer and Franklin 1997, Bunnell 2008). Species diversity may be associated with the presence and abundance of structural features as well as with the variability of these features in terms of their size, growth stage, and state of decay. To understand the effects of forest practices on species diversity, it is important to study potential drivers of this diversity such as the abundance and variability of coarse woody material, including standing dead stems (snags) (Drapeau et al. 2009, Lowe et al. 2011) and downed wood (Crites and Dale 1998, Dechene and Buddle 2010), as well as tree size diversity, spatial variability in microtopography (e.g., pitsand-mounds), and forest floor characteristics (Spies 1998).

\section{Coarse woody material sub-plots}

Since the 1970s, forest managers worldwide have been encouraged to allow dead trees and coarse woody material (CWM) to remain in forests after logging. Coarse woody material refers to fallen dead trees and the remains of large branches on the ground. A dead standing tree, also known as a snag, provides many of the same functions as CWM. These functions include recycling nutrients trapped in the wood and providing food and habitat for a wide range of organisms, thereby improving biodiversity ${ }^{9}$. Coarse woody material was

\footnotetext{
${ }^{9}$ Source: https://en.wikipedia.org/wiki/Coarse_woody_debris
} accessed May 16, 2017. 
assessed pre- and post-harvesting within three $400 \mathrm{~m}^{2}(20 \mathrm{~m}$ x $20 \mathrm{~m}$ ) sub-plots in three replicates of selected treatments (soil sub-plots in Fig. 2). The assessment of CWM had two objectives: to quantify the type and amount as related to biodiversity and to determine carbon and nutrient contributions to the soil. In this study, CWM includes standing dead trees, also known as snags $(\geq 1.5 \mathrm{~m}$ in height and $\geq 5 \mathrm{~cm}$ in diameter), stumps ( $<1.5 \mathrm{~m}$ in height and $\geq 5 \mathrm{~cm}$ diameter), suspended dead trees (not in contact with the ground, $\geq 1 \mathrm{~m}$ in length and $\geq 5 \mathrm{~cm}$ in diameter) and downed material ( $\geq 1 \mathrm{~m}$ in length and $\geq 5 \mathrm{~cm}$ in diameter). Within the plots, each piece was identified to species (where possible), measured, and assigned a decay class based on those identified by Duvall and Grigal (1999). Pre- and post-harvesting volumes were calculated for stumps, suspended, downed woody debris, and standing dead trees following methods published by Harmon and Sexton (1996).

Pre-harvest CWM volume varied among sites. The downed and standing component dominated the pre-harvesting CWM at all sites. Two-years post-harvesting (Fig. 4), the volume of CWM in the intensive and elite treatments was less than half that in the unharvested natural plots at the Sioux Lookout and Dryden sites. In the case of the Timmins and Petawawa sites, CWM was higher in the intensive and elite than in the unharvested natural plots. At all sites, the volume in the standing category was reduced as expected and the volume in the stump category was generally greater in the harvested compared with the unharvested natural plots. The stump volumes that occurred in the unharvested plots were associated with trees that had died and decayed.

\section{Forest floor transects}

Post-harvest forest floor structure surveys were conducted within two to three years post-harvest using transects (described below) in all experimental units to quantify site characteristics, such as the extent of site preparation trenches, bare ground, rock, wet holes, unharvested areas, slash, berms (soil and organic material mixed and piled from road building, site preparation, or other skidding), and CWM. Here, CWM is included as a feature that contributes to microsite variability, which differs from the CWM volume estimates described above.

In each experimental unit, $400 \mathrm{~m}$ linear transects were systematically positioned perpendicular to the pattern of major disturbances such as site preparation. To describe the treatment accurately, lines were placed to best cover the treatment plot (either lengthwise using $200 \mathrm{~m}$ transects or across the experimental unit using $100 \mathrm{~m}$ transects). Some conditions for sampling were applied, for example, CWM had to meet the minimum requirement of $5 \mathrm{~cm}$ in diameter but did not have to be $1 \mathrm{~m}$ in length. Where disturbances overlapped, only the uppermost disturbance was assessed, for example, if a slash pile was placed over a skid trail, only the slash pile was recorded. Weather at the time of assessment was also noted since rain or drought could influence the amount of pooled water recorded.

As silviculture intensified, the amount of undisturbed area decreased and the area in berms and exposed soil increased (Fig. 5). This change can be attributable to the use of site preparation equipment. In order to meet the stocking levels associated with higher silvicultural intensities, it was deemed necessary to increase the number of plantable sites through the use of mechanical site preparation.

\section{Maintenance of Productive Capacity of Forest Ecosystems}

Maintaining or enhancing fibre quantity research is being conducted using permanent growth and yield and stocking plots.

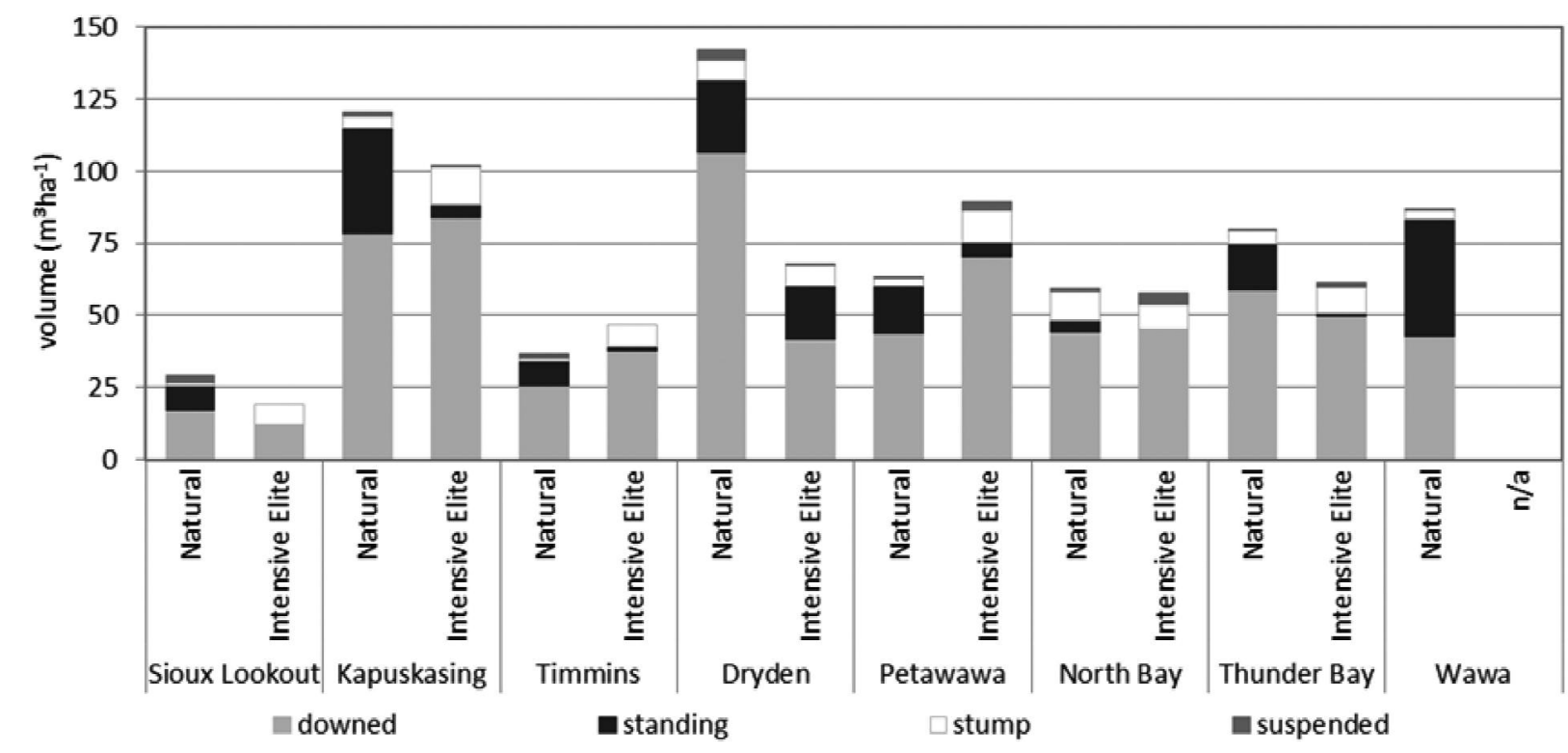

Fig. 4. Volume of coarse woody material in the natural plots and intensive and elite plots 2 years post-harvesting by NEBIE plot network site. 


\section{a) Extensive}

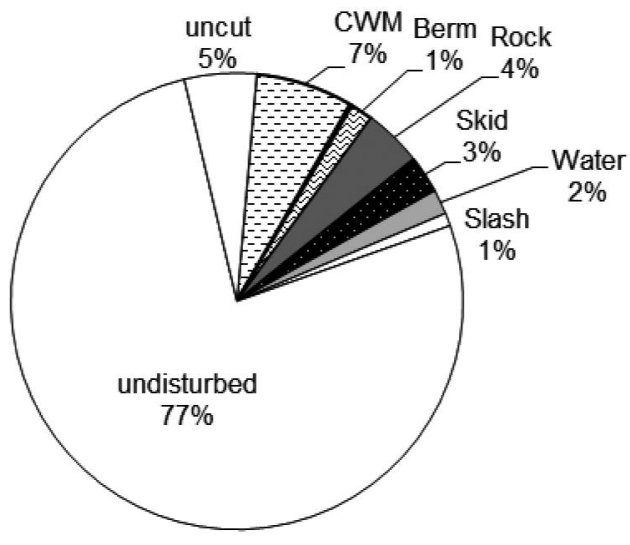

c) Intensive

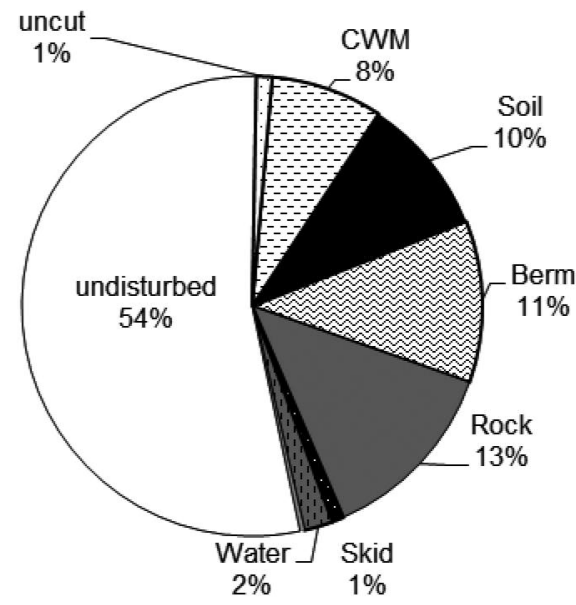

b) Basic

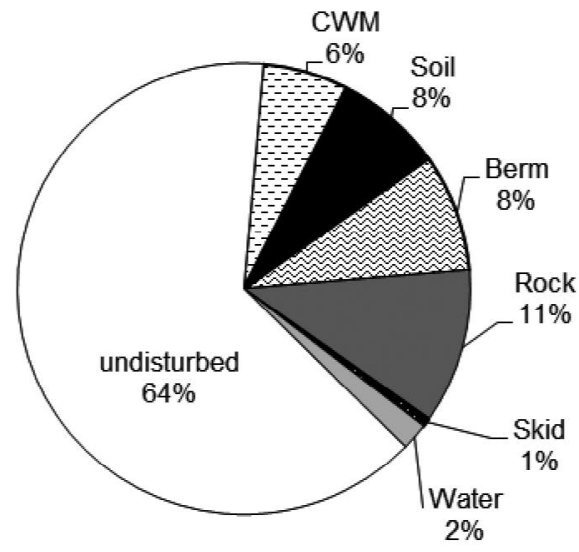

d) Elite

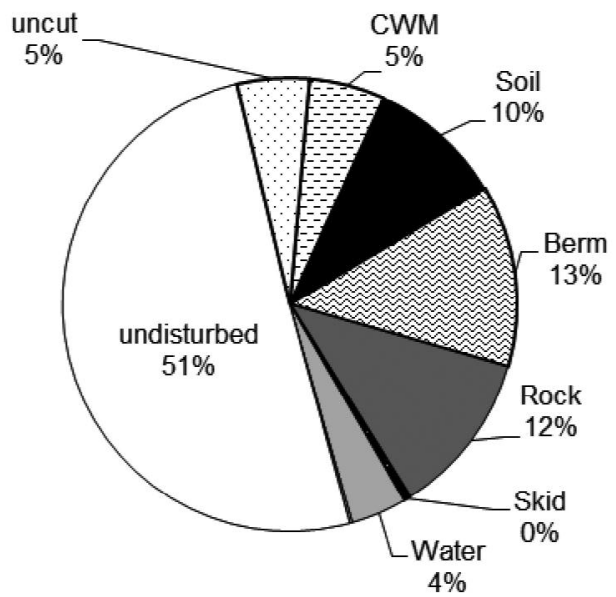

Fig. 5. Influence of intensification-(a) extensive, (b) basic, (c) intensive, and (d) elite-of silviculture on the percent surface cover of various forest floor components at the Dryden site of the NEBIE plot network. The data is based on a survey conducted two years postharvest.

\section{Growth and yield plots}

Since 1956, Plonski's normal yield tables, or variants thereof, have been used for forest management planning on public lands in Ontario. Recently, it was identified that Plonski's yield tables no longer met all the needs of foresters trying to ensure a continuous flow of products and values from forested land as they fail to account for the role of silviculture in manipulating stand composition and structure (Sharma et al. 2008).

Crop tree growth and yield is being monitored on four $400 \mathrm{~m}^{2}$ (11.28 m radius) permanent plots randomly located within each experimental unit (one for each growth and yield sub-plot in Fig. 2). The plots were assessed pre-harvest and 2-, $5-$, and 10-years post-harvesting following methodology adapted from Ontario's growth and yield program protocols for permanent growth plot tree samples (Hayden et al. 1995, OMNR 2009a).

In each growth and yield plot, live trees with a diameter at breast height $(\mathrm{DBH}) \geq 2.5 \mathrm{~cm}$ and live trees considered a small species (e.g., Sorbus sp.) with a DBH $\geq 7.5 \mathrm{~cm}(\mathrm{OMNR}$ 2009a) were measured. All dead trees with a $\mathrm{DBH} \geq 10 \mathrm{~cm}$ and height $\geq 2 \mathrm{~m}$ at plot establishment and all previously assessed live trees that died were measured. For live trees, species, status (i.e., live, veteran), DBH, crown class (e.g., dominant, intermediate, and understory), quality, and deformity information were recorded. For dead trees, species, status (i.e., dead, dead veteran), height, $\mathrm{DBH}$, and decay class were recorded. All measurements were taken after the growing season. Live tree data were used to determine tree species composition, volume of standing timber, tree crown characteristics, and tree health and vigour. Dead tree data were used to determine the volume of standing timber that could become downed wood and the degree of stem decay occurring within a given treatment.

Individual tree gross total and merchantable volumes were estimated using Honer et al's (1983) equations 14 and 22. Top heights for merchantable timber were defined in the Ontario 


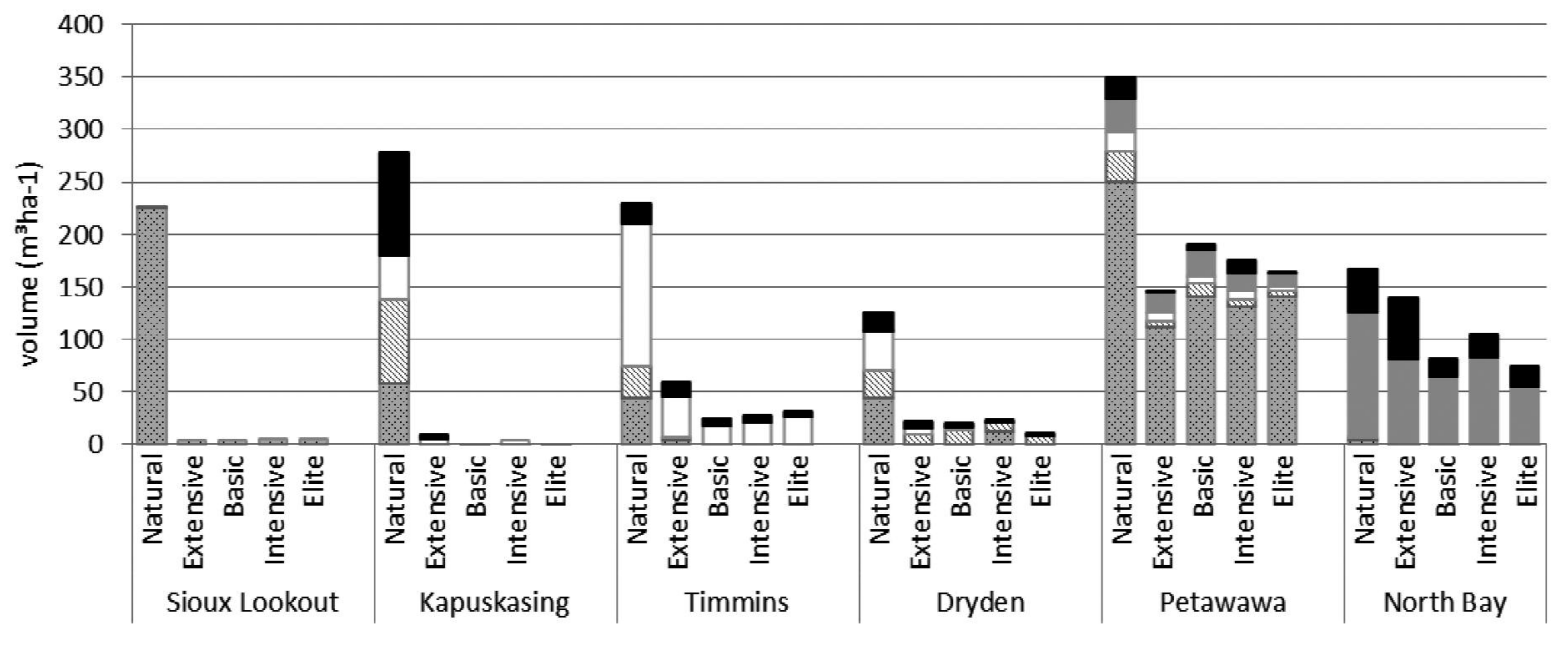

圆 spruce and pine $\quad$ other conifer $\square$ trembling aspen $\quad$ maple $\quad$ other hardwood

Fig. 6. Tenth-year total volume by plot type and NEBIE plot network site for each tree species grouping

Scaling Manual (OMNR 2007) and a constant stump height of $40 \mathrm{~cm}$ was used. Heights were estimated with the TCM-PAM (Timber Cruising Model-Plot Assessment Model) application based on DBH (Zakrzewski 2001, unpublished data).

Total volume in the unharvested natural forest varied greatly among sites (Fig. 6). Total volume was highest in the northern temperate mixedwood at the Petawawa site and lowest in the boreal mixedwood at the Dryden site. Tenthyear post-harvesting total volumes varied by site and treatment (Fig. 6). The extent that residual trees-stems left behind during harvesting to fulfill the requirements of the guide for natural disturbance pattern emulation in clearcuts (OMNR 2001) and those remaining following shelterwood systems - contribution to the 10-year post-harvesting volume varied depending on the silviculture system used at each site (Fig. 6). At the Sioux Lookout site, where a full-tree clearcut system was used, no volume remained in the treated plots; therefore, the 10-year volume fully represents the regenerating species. In contrast, at the North Bay and Petawawa sites where shelterwood systems were used, a large proportion of the 10-year volume was from the residual trees.

\section{Stocking plots}

Stocking plot assessments are used to quantify tree species regeneration, providing information that can be used to determine if regeneration standards have been achieved (see Sharma et al. 2010) and to forecast future stand development (see Homagain et al. 2011). In mixedwood forests, and perhaps other forest types, free-to-grow regeneration standards are generally not well linked to growth and yield (Lieffers et al. 2007).

On the NEBIE plot network, species regeneration (i.e., composition, stocking, and density) is being monitored using ten, $4 \mathrm{~m}^{2}(2 \times 2 \mathrm{~m})$ stocking plots within the four growth and yield sub-plots in each experimental unit (Fig. 2). Stocking is defined as the occupancy of a $4 \mathrm{~m}^{2}$ plot by at least one tree. An $80 \%$ stocked stand would have at least 2000 stems ha-1. Data collected in the stocking plots included species, weighted height, percent foliar cover, and number of stems < $2.5 \mathrm{~cm}$ in DBH by height class $(<50 \mathrm{~cm}, 50$ to $130 \mathrm{~cm}$, and $>130 \mathrm{~cm}$ to $<10 \mathrm{~m}$ ). To improve links to growth and yield information, the stocking plots were located within the growth and yield plots (see Fig. 2).

At year 10, the majority of treatments achieved stocking targets set for 'objective trees' in the silvicultural objectives (Fig. 7). As the silviculture intensity increased there was a shift in the suitability of objective species. For example, at the Timmins and Dryden sites, all tree species were considered desirable in the extensive treatment but only spruce and aspen were considered desirable as objective trees in the intensive and elite treatments at Timmins and spruce and pine were considered desirable as objective trees at Dryden. At Dryden, aspen and balsam fir were considered in the other category in intensive and elite treatments. Thus, stocking in extensive can appear to be higher than in intensive or elite (Fig. 7). Trees considered small, e.g., pin cherry (Prunus pensylvanica L. f.), mountain ash (Sorbus sp.), and willow (Salix sp.) were not included in these calculations. In a subsequent paper, the authors will assess how well the NEBIE silvicultural objectives have been achieved for each site and treatment. This will greatly help in subsequent analysis and presentation of results. Further details are provided in the "Caution for interpretation of results" section.

\section{Maintenance of Forest Ecosystem Health and Vitality}

Research on reducing the risk of wood fibre losses is focused on pathology studies and monitoring exotic species, but may also include studies on the effects of insects, fire, and severe weather if such events occur. 


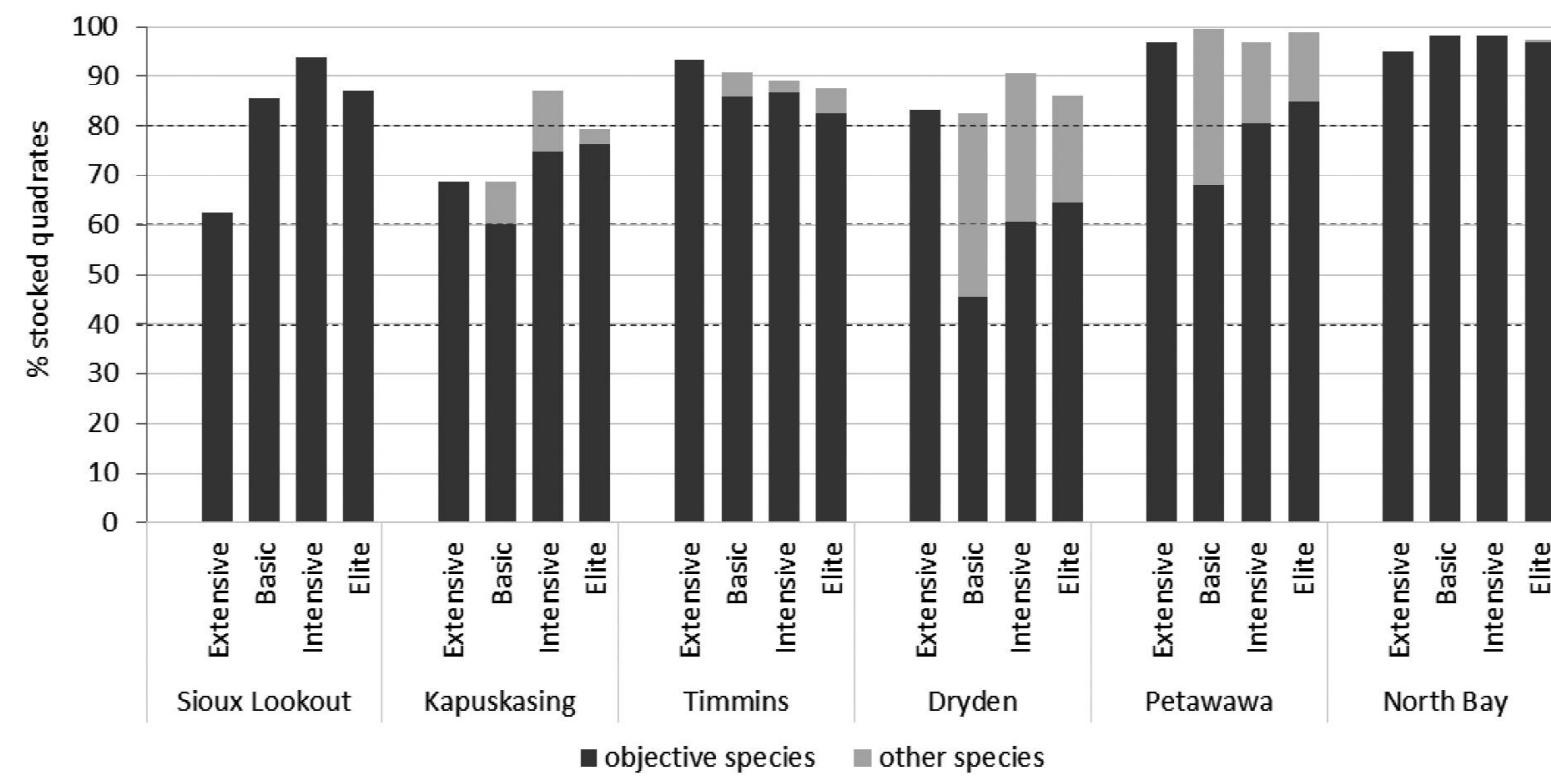

Fig. 7. Stocking of species identified in the silvicultural objectives for each site and treatment (see Bell et al. 2017) and of other tree species by treatment and site in the NEBIE plot network. Dashed lines at 40\%, 60\%, and 80\% indicate the target stocking for the extensive, basic, and intensive, and elite treatments, respectively. Stocking is defined as the percent of $2 \mathrm{~m} \times 2 \mathrm{~m}$ quadrats containing at least one tree, $n=160$ per treatment with the exception of Timmins and North Bay, $n=120$.

\section{Pathology studies}

One of the criteria used to assess sustainability of the treatments is the risk of losses to target trees. To understand one aspect of this risk, we are monitoring root and butt rot disease populations. Future studies could include other disease or insect populations.

The objectives of the root and butt rot surveys were to: (i) determine the occurrence, incidence, severity, and effect of root and butt rot pathogens on the NEBIE plot network sites; (ii) assess uniformity of disease incidence and severity across plots within and among blocks at each site; (iii) clarify site and host preferences of various Armillaria species; (iv) identify the relationships between Armillaria species and disease severity; and, (v) track the development of disease, mortality, and internal decay in the developing stands in relation to a variety of site, host, and management variables.

Pre-harvest field surveys and sampling of dead or declining trees was conducted in 2002 at the Timmins and Sioux Lookout sites and in 2003 at the Kapuskasing site. Post-harvesting sampling of the stumps of the recently harvested live trees was conducted the following year (2003 and 2004, respectively). The pre-harvesting survey at the Thunder Bay installation was conducted in 2005 , followed by post-harvesting sampling in 2009. For the pre-harvesting survey, three circular sample plots were randomly located in each of the extensive, basic, intensive, and elite treatments in all four blocks. The plot size was 200 or $400 \mathrm{~m}^{2}$ depending on tree density. Every tree, living or dead, with a DBH greater than $2.5 \mathrm{~cm}$ was assigned, according to Hayden et al. (1995), a health code and a crown class rating relative to its canopy position. In two of the three plots, living trees with a $\mathrm{DBH}$ greater than $10 \mathrm{~cm}$ were tagged for the post-harvesting sampling. Dead trees were assigned a decay class and investigated for Armillaria spp. and other root rot pathogens. Samples (typically from diseased roots) from dead and declining trees were collected and transported to the laboratory to identify the cause of death or decline. In the post-harvesting sampling, tagged stumps were revisited. Wood samples were collected from those exhibiting internal staining or decay. Identification of pathogens and decay fungi isolated from the samples was accomplished through traditional (e.g., culturing, microscopy, chemical reagent tests) and molecular e.g., (DNA sequencing) means (McLaughlin 2008).

In all, 7826 trees, including 543 dead trees $>10 \mathrm{~cm} \mathrm{DBH}$, were assessed at four sites included in the pathology study. Cultures representing 23 wood-decaying species were identified, 15 of which have been previously described as significant root disease or butt-rot fungi in Ontario forests (Basham and Morawski 1964, Whitney 1995). Armillaria ostoyae (Aost.) and A. sinapina (Asin.) were by far the most common pathogens associated with most of the tree disease and mortality observed on all sites, and often were isolated with other known root disease and decay fungi from the same diseased root. Data from the Sioux Lookout site supported observations by Whitney (1995) that A. ostoyae is the primary Armillaria species causing root disease in pure conifer stands. Interestingly, A. sinapina, which was almost absent in the pure conifer stand, played a significant role as a root disease pathogen of both conifers and hardwoods on the boreal mixedwood (Timmins and Kapuskasing) and boreal hardwood (Thunder Bay) sites (Fig. 8a). Post-harvest stump samples showed that $A$. ostoyae and $A$. sinapina caused most of the staining and butt rot observed on all sites, but other known butt rot fungi were also frequently isolated (Fig. 8b).

The pre- and post-harvesting surveys provide data to support analyses related to the first four objectives of the pathol- 
a)

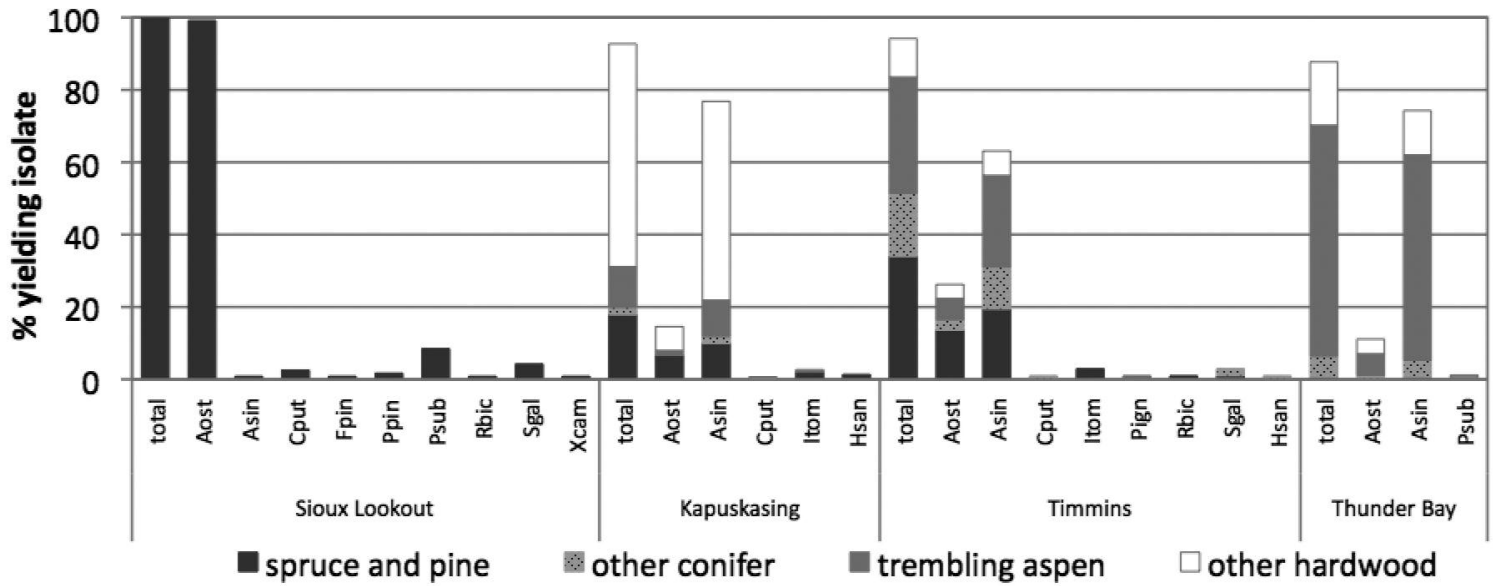

b)

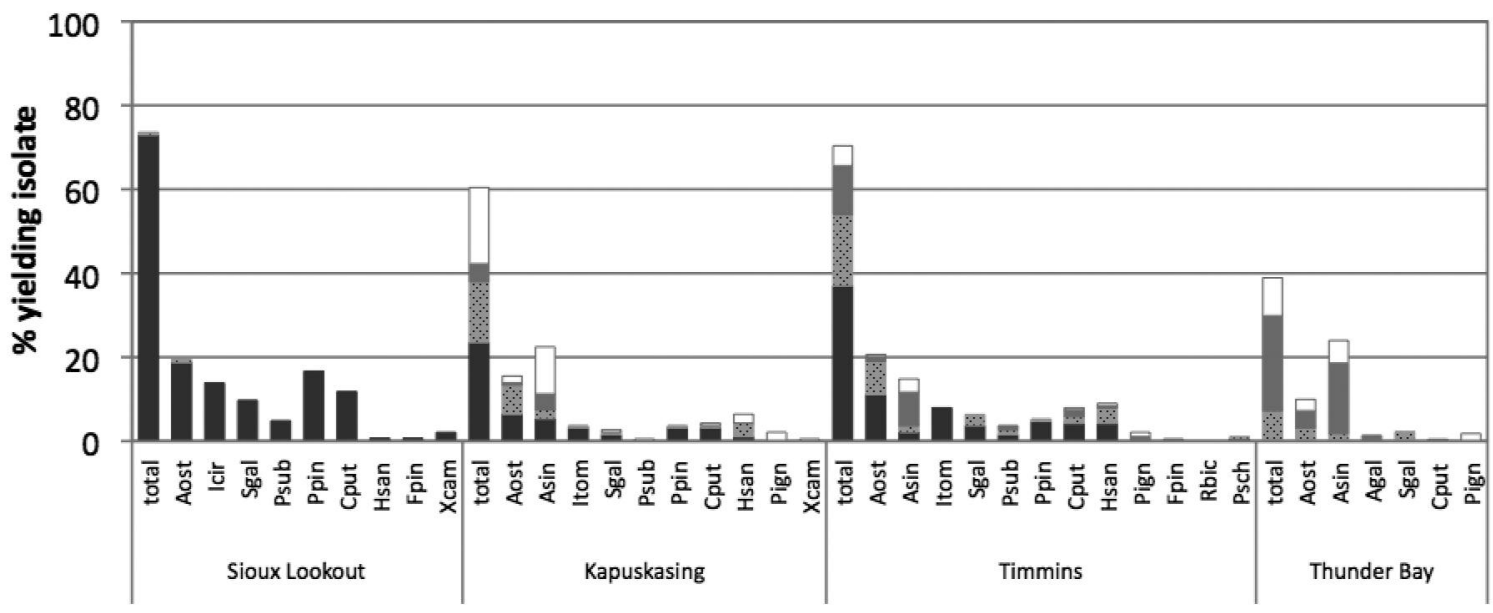

aspruce and pine $\quad$ other conifer $\quad$ trembling aspen $\square$ other hardwood

Fig. 8. Isolations of (a) root- and butt rot fungi from pre-harvesting samples of dead trees $>10 \mathrm{~cm}$ in diameter at breast height and (b) decay fungi from post-harvesting samples of stumps tops exhibiting staining or decay on four of the NEBIE plot network sites. Agal Armillaria gallica Marxm. \& Romagn., Aost - Armillaria ostoyae (Romagn.) Herink, Asin - Armillaria sinapina Bérubé \& Dessur., Cput Coniophora puteana (Schumach.) P. Karst., Fpin - Fomitopsis pinicola (Sw.) P. Karst., Hsan - Haematostereum sanguinolentum (Alb. \& Schwein.) Pouzar, Icir - Inonotus circinatus (Fr.) Teng Itom - Inonotus tomentosus (Fr.) Teng, Psub - Perenniporia subacida (Peck) Donk, Psch - Phaeolus schweinitzii (Fr.) Pat., Pign - Phellinus igniarius (L.) Quél., Ppin - Phellinus pini (Brot.) A. Ames, Rbic - Resinicium bicolor (Alb. \& Schwein.) Parmasto, Sgal - Scytinostroma galactinum (Fr.) Donk, Xcam - Xeromphalina campanella (Batsch) Kühner \& Mairea]

ogy aspects of the study. Future work in pursuit of tracking disease progression will include periodic surveys of the plots to identify correlations among the incidence of Armillaria root disease and tree species, age, crown class, and $\mathrm{DBH}$, site characteristics (soil $\mathrm{pH}$, texture), and silviculture treatment.

\section{Exotic plant species}

Exotic plant species are monitored using the vegetation diversity plots. Using the NEBIE plot network, we are interested in determining if northern temperate or boreal forests are prone to invasion following varying intensities of silvicultural disturbances, and if so, what might be the main drivers con- tributing to biological invasion of these forests. Based on biological invasion theory we presume that the highest richness of exotic species will be observed in plots treated with intermediate levels of disturbance (i.e., the basic treatments) (Catford et al. 2012, Bell 2015). The highest richness of exotic species at year 10 was observed in basic silviculture treatments. We presume that the majority of the exotic species will not survive following crown closure. On a relative scale, we presume that in year 50 post-harvest, the highest richness of exotics species will exist in the intensive and elite treatments following thinning treatments. 
Conservation and maintenance of soil and water resources Soil nutrients

We are interested in the long-term effects of silvicultural intensification on (i) soil organic carbon (C), total nitrogen $(\mathrm{N})$, and base cation pools [calcium $(\mathrm{Ca})$, magnesium $(\mathrm{Mg})$, and potassium $(\mathrm{K})$ ], and (ii) the $\mathrm{C}$ and nutrient contents of downed wood/fine woody material (FWM) and coarse woody material (CWM). We anticipated that the FWM would decompose quickly, providing a source of nutrients for seedlings in the early stages of growth. In contrast, CWM would act as a long-term (decades to centuries) $\mathrm{C}$ and nutrient sink. Therefore, the downed wood component of the NEBIE plot network addresses the distribution of FWM and CWM and their C and nutrient contents after silviculture intervention and the long-term implications for site productivity.

Two types of soil surveys, baseline and enhanced, are being conducted on the NEBIE plot network sites in the soil sub-plots (Soil-CWM plots in Fig. 2). Baseline surveys, which consisted of CWM surveys and sample collections of soil organic matter (OM) and FWM, were completed on all sites pre-harvesting and at most sites two years post-harvesting. Enhanced soil surveys were conducted at the Sioux Lookout (sandy), Kapuskasing (clay), and Timmins (sandy to silty loam) sites, as they represent the range of project site soil types.

Enhanced surveys were conducted to test the hypothesis that intensification of silviculture will lead to a reduction in soil nutrients and that this loss will be attributable to the removal of foliage during harvesting of mature trees and thinnings (Burger 2002). The enhanced survey included pre-, 2-, and 5-year post-harvesting mineral soil, FWM, and OM and sample collection for litter (yearly input of branches, leaves), In 2011, we also collected basic soils data including soil texture, $\mathrm{pH}$, moisture regime, drainage class, and other variables following OMNR (2009b). Mineral soil sampling was conducted using soil cores of $10 \mathrm{~cm}$ increments to $1 \mathrm{~m}$ depth at the same location as the FWM and OM, where possible. Fine woody material and OM sampling were conducted using four $25 \mathrm{~cm}^{2}$ templates per soil sub-plot. In the lab FWM was sorted into branches $(<0.5,0.5-1$ and $>1-2.5 \mathrm{~cm})$, bark, cones, and other OM into humus, roots, and wood. Leaf litter was collected from four $1 \mathrm{~m}^{2}$ frames within one of the soil sub-plots. Dry weights were obtained for mineral soil, FWM, leaf litter, and OM samples. Samples collected from the enhanced sites were analyzed for organic C, N, and base cations. Pre-harvesting and 2-, and 5-year post-harvesting $\mathrm{C}$ and total $\mathrm{N}$ information for the three enhanced sampling sites are presented in Fig. 9.

\section{Maintenance of forest contribution to global carbon cycles Carbon sequestration}

Forests cover $65 \%$ of the total land surface; they contain $90 \%$ of the total vegetation $\mathrm{C}$ in terrestrial ecosystems, $80 \%$ of the total soil C in terrestrial ecosystems, and assimilate $67 \%$ of the total $\mathrm{CO}_{2}$ removed from the atmosphere by all terrestrial ecosystems (Gower 2003). The scientific community, forest managers and policy-makers require information on the amount of carbon stored in forest ecosystems.

Following the completion of growth and yield, CWM, and soil nutrient data, it will be possible to determine the effect of intensification of silviculture on terrestrial (or biologic) car- bon sequestration. The actual rate of carbon sequestration varies with tree species, age, climate, and site conditions but, in general, younger, faster growing, fully stocked stands have higher annual sequestration rates. This information is critical to determine if forests are carbon sources or sinks over long time periods.

It is essential to quantify forest carbon stocks and their rate of carbon sequestration and evaluate the effects of intensification of silviculture and different forest management options. We propose to use the TRIPLEX (Peng et al. 2002), a hybrid model with monthly time step, to quantify the effect of intensification of silviculture on terrestrial (or biologic) carbon sequestration. TRIPLEX was built by borrowing a soil carbon, nitrogen, and water balance sub-model from CENTURY4.0 (Parton et al. 1993), a process-based forest growth sub-model form 3-PG (Landsberg and Waring 1997), and a growth and yield sub-model from TREEDYN3.0 (Bossel 1996). The resulting hybrid model can be used to simulate carbon, nitrogen, and water cycling processes such as photosynthesis, carbon allocation, nitrogen mineralization, and evapotranspiration, and to predict stand growth and yield (Zhou et al. 2004; Zhou et al. 2005) for forest management (Wang et al. 2011, 2012, 2013) in Canadian boreal forests.

\section{Maintenance and enhancement of long-term multiple socio-eco- nomic benefits \\ Fibre quality}

Research related to maintaining or enhancing fibre quality involves harvesting plots allocated to destructive sampling. As well, trees with anomalous growth forms (e.g., broken from physical or logging damage or bent by snow pressure) are recorded during growth and yield surveys. Other quality aspects recorded include presence of defoliation, crown dieback, stem injuries, root exposure, and logging damage. Intrinsic wood quality properties can be monitored once the trees reach maturity using the destructive sampling sub-plots.

\section{Benefit cost analysis}

Research related to maintaining economic sustainability will be initiated following collection of the 10-year post-harvesting data. We anticipate conducting stand-level economic analyses using procedures developed by Insley (2002) and Homagain et al. (2011). A supplementary analysis will be conducted for the North Bay site to determine the additional benefits of managing non-timber forest products. Canada yew (Taxus canadensis) is commercially harvested from the understory of forests throughout eastern Canada and sold to pharmaceutical companies for production of the anti-cancer drug Taxol (Noland et al. 2011). It was established in the intensive plots on the North Bay study site.

\section{Summary}

The NEBIE plot network was designed to evaluate the suitability and sustainability of intensive forest management across a range of ecological regions of Ontario. While different types of silviculture treatments have been previously evaluated, the NEBIE plot network does this at a much larger scale, and with a wider range of intensities, in a variety of common forest types. The operational scale of the treatment plots allows for the assessment of biological diversity, productivity, ecosystem health, soils, and other measures of forest sustainability over the entire life of the stand. This is a unique 
a)

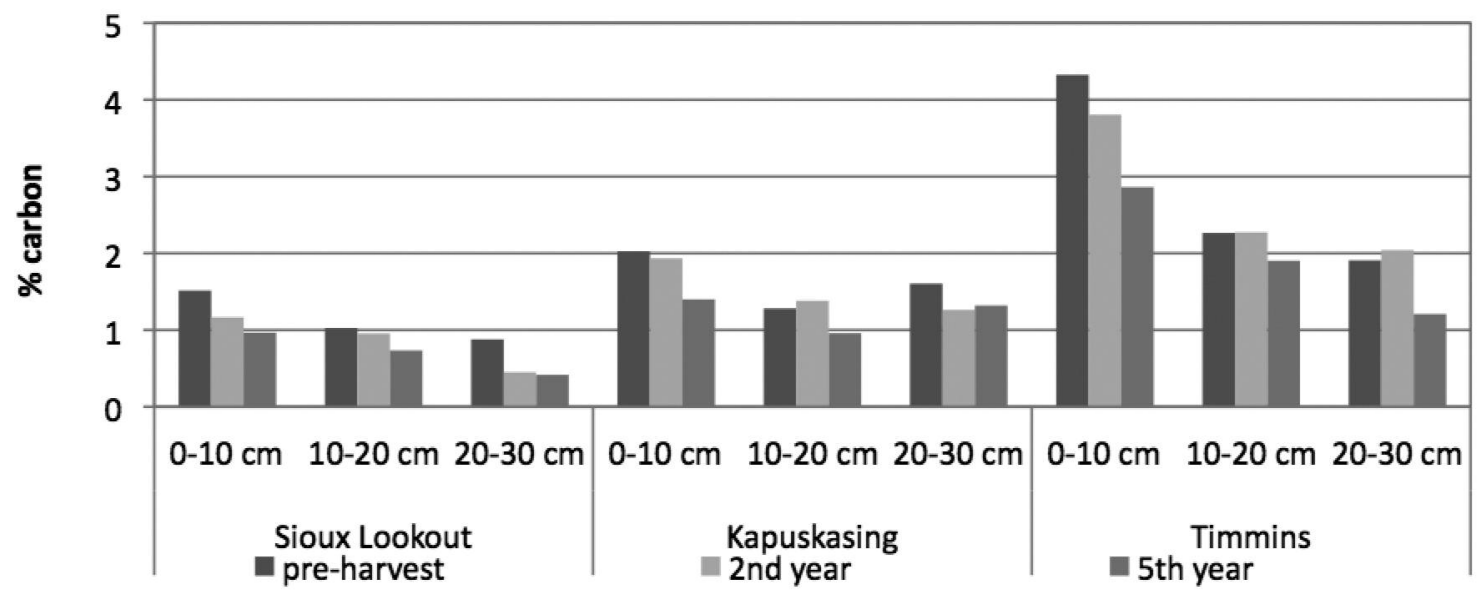

b)

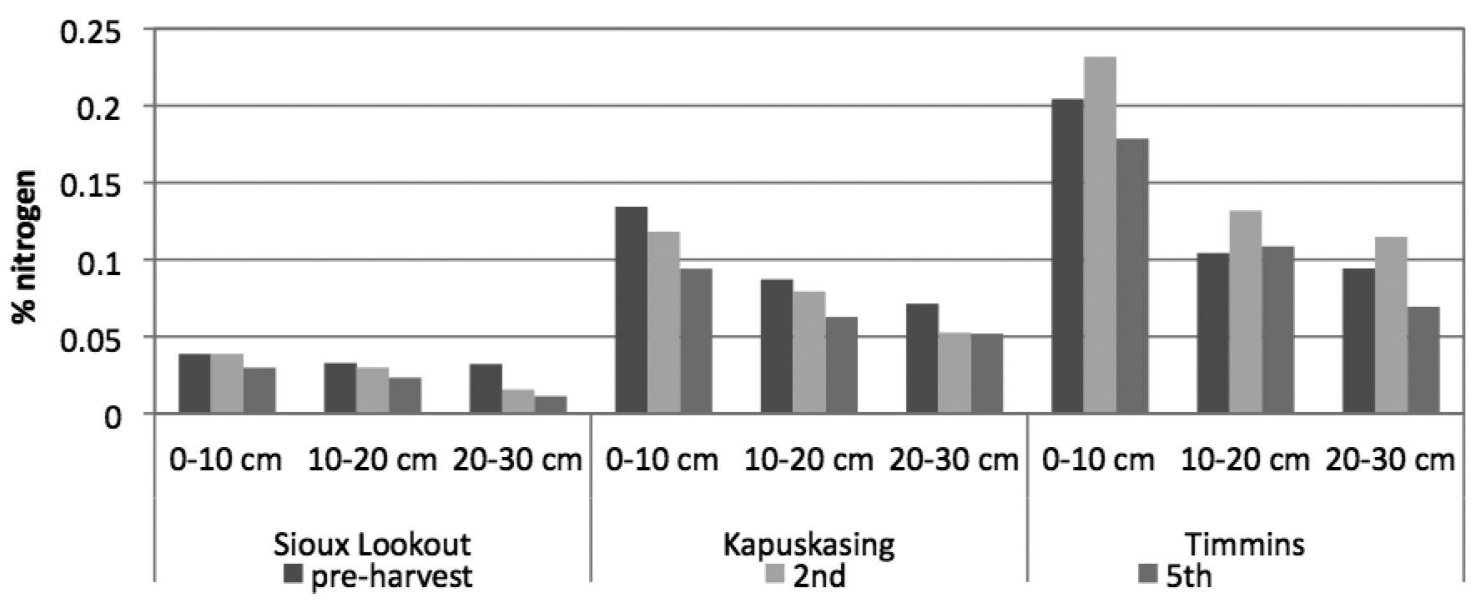

Fig. 9. Pre-harvesting, and 2-, and 5-year post-harvesting mineral soil (a) \% carbon, (b) \% nitrogen by depth class (cm) at the Sioux Lookout, Timmins, and Kapuskasing sites of the NEBIE plot network.

feature of this network of experimental installations. The scope of data collected as well as its consistency and continuity exceeds the majority of other harvesting and silvicultural experiments.

At this stage of the project, pre-treatment and 2-, 5-, and most of the 10-year post-harvesting data have been collected. These initial data provide added information on the productivity, biodiversity, soils, and fungal communities of these forests. While it is too early to evaluate what other advances in knowledge may result from this work, information from the NEBIE plot network is likely to improve our understanding of gains in productivity and wood value resulting from more intensive silviculture treatments. Since the intensification of treatments along the continuum of the NEBIE framework represent changes in several silviculture practices (stocking, vegetation control), it will not be possible to discern the specific variables responsible for changes in plantation productivity. However, the operational design of the project will enable us to study trade-offs between forest productivity and biodiversity, nutrient cycling, and other features of forest ecology.

Scientists from OMNRF and professors from several universities in Ontario including Lakehead, Guelph, and Waterloo, have been involved in the project. They are using some or all of the sites to answer specific questions related to ecologi$\mathrm{cal}$ and economic aspects of the NEBIE plot network. Additional opportunities for scientific collaborations are many and efforts are ongoing to bring more scientific expertise to the network, including graduate students and their supervisors. Efforts will also be made to make the base data available to collaborators.

Now, and in the future, the NEBIE plot network will provide a base for advancing science and training foresters and professionals in new silvicultural activities. It also provides venues for public education/awareness of the value of forest management. 
a) Spruce and Pine (Picea sp. and Pinus sp.)

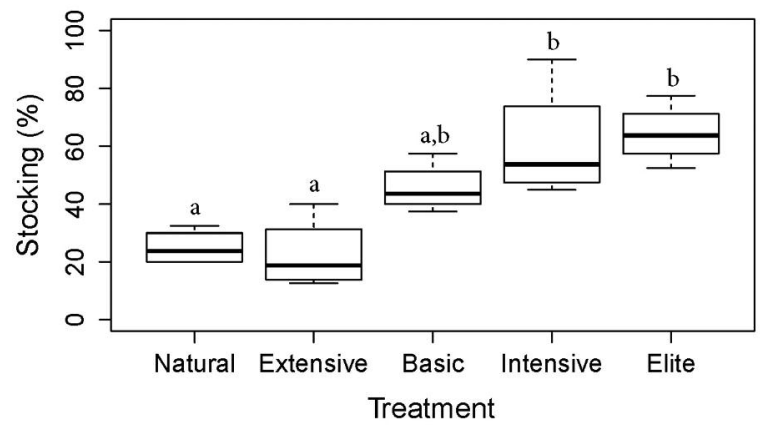

c) Hardwood species (Betula papyrifera Marsh.,

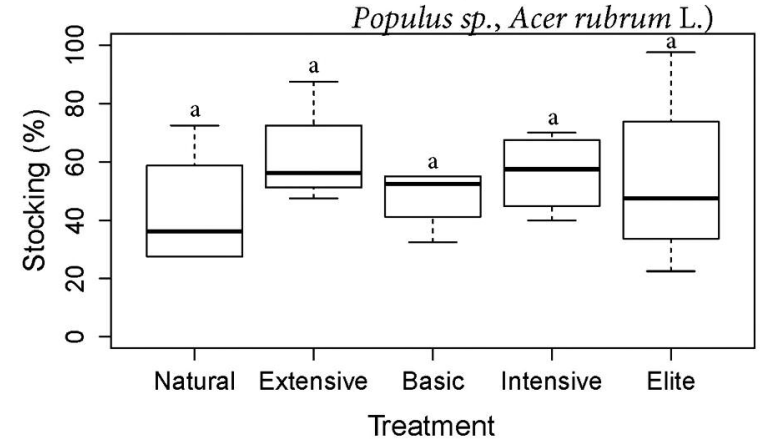

b) Balsam fir (Abies basamea L.)

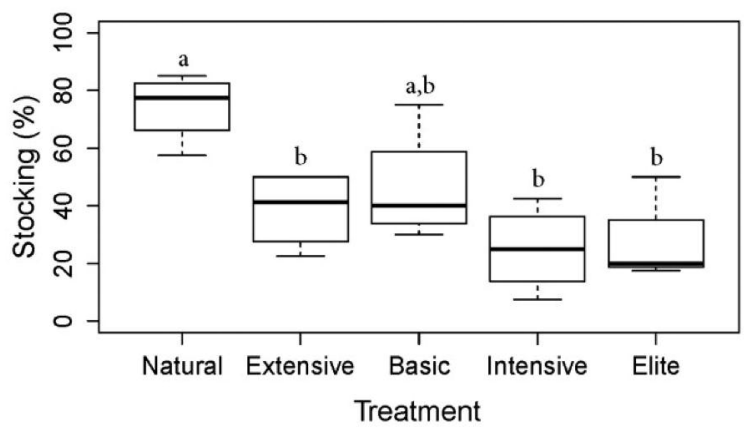

d) All species

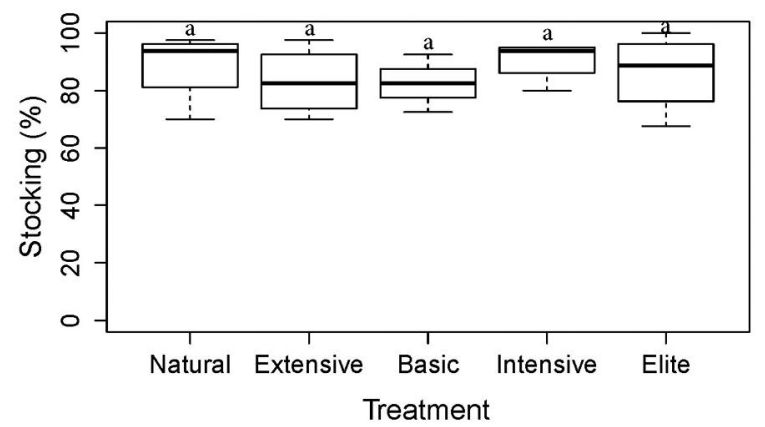

Fig. 10. Percent stocking by Dryden NEBIE treatment $(n=4)$ and species groups (a) spruce and pine consisting of Picea sp. and Pinus sp.; (b) balsam fir (Abies balsamea); (c) hardwood species consisting of Acer rubrum, Betula papyrifera, Fraxinus nigra, Populus balsamifera, and P. tremuloides and (d) all species consisting of Abies balsamea (L.), Acer rubrum L., Betula papyrifera Marsh., Fraxinus nigra Marsh., Picea glauca (Moench) Voss, P. mariana (Mill.) BSP, Pinus banksiana Lamb., P. resinosa Ait., Populus balsamifera L., P. tremuloides Michx., and Thuja occidentalis L. Stocking is defined as the percent of $2 \mathrm{~m} \times 2 \mathrm{~m}$ quadrats containing at least one tree. Lower case letters above plots indicate difference in treatments at a 95\% family-wise confidence level from a Tukey multiple comparisons of means. Note: horizontal lines in the box and whisker plots are medians and the boxes represent $25^{\text {th }}$ to $75^{\text {th }}$ percentiles.

\section{Caution for interpretation of results}

In this paper, we deliberately limited the statistics to the calculation of means and standard deviations. The intent of the paper was to make the reader aware of the types of studies being conducted; thus, complex statistical analyses, such as those published in Bell et al. $(2014,2016)$ were not presented in this paper. Detailed analyses of data will be forthcoming.

The reader of this paper should also note that at time of publication, i.e., $10^{\text {th }}$ year post-harvest, the intensive and elite treatments were incomplete. Thinnings are scheduled for intensive and elite treatments and prunings and fertilizations are scheduled for the elite treatments (see Appendix 1 in Bell et al. 2017). Thus, rigid interpretation of results may be premature.

To show the complexity of the data, we conducted a prototype of a simple analysis of the stocking data. Two-way ANOVAs appropriate for our study design were performed to determine if the percent stocking differed for NEBIE treatments, 10 years post-harvest. Four groups of species were tested: all species consisting of Abies balsamea [L.], Acer rubrum L., Betula papyrifera Marsh., Fraxinus nigra Marsh., Picea glauca (Moench) Voss, P. mariana (Mill.) BSP, Pinus banksiana Lamb., P. resinosa Ait., Populus balsamifera L., P. tremuloides Michx., and Thuja occidentalis L.; spruce and pine consisting of Picea spp. and Pinus spp., Abies balsamea; and hardwood consisting of Acer rubrum, Betula papyrifera, Fraxinus nigra, Populus balsamifera, and $P$. tremuloides. Tukey posthoc comparisons were performed to look at the difference between NEBIE treatments for each species group. Fig. 10 shows the distribution of percent stocking by NEBIE treatment and species groups. Differences between treatments $(p<0.05)$ were noted for the spruce and pine and balsam fir groups.

\section{Acknowledgements}

We thank the Ontario Ministry of Natural Resources and Forestry (OMNRF), Upper Lakes Environmental Research Network, University of Guelph, Canadian Ecology Centre-Forestry Research Partnership (CEC-FRP), and Forest Ecosystem Science Co-op (FESC) for supporting and comanaging the NEBIE Plot Network. The NEBIE Plot Network was supported by financial grants from the Living Legacy Trust (LLT), Forestry Futures Trust (FFT)'s Enhanced Forest Productivity Science Fund, National Science and Engineering Research Council of Canada (NSERC), the Canada Foundation for Innovation/Ontario Innovation Trust, and Campbell Scientific. 
We gratefully acknowledge the dedication and support provided by our forest management, research, and transfer partners including the former CEC-FRP, the Canadian Institute of Forestry, Clergue Forest Management Inc., Domtar Inc., EACOM Timber Corporation Inc., FESC, FPInnovations - FERIC Division, Green Forest Management Inc., Lakehead University, OMNRF, Natural Resources CanadaCanadian Forest Service (CFS), Nipissing Forest Resource Management Inc., Resolute (formerly Abi-Bow Inc.), Sault College, Tembec Inc., University of Guelph, University of Waterloo, and Weyerhaeuser Inc.

We are indebted to Sharon Cuddy (ULERN) and Dianne Miller (FESC) for management of LLT funds and FFT funds, respectively; Jim Baker, David DeYoe, and Dan Puddister for administrative support within OMNRF; Doug Pitt (CFS) for advice on the experimental design; Amy Bolduc, Ray Ferguson, Mya Rice and many others (OMNRF) for trial installation and data collections; Jim McLaughlin, Rachelle Lalonde and Peter Uhlig (OMNRF) for soils expertise.

We also extend our thanks to Victor Lieffers, Paul Hazlett, Ken Lennon, Maureen Kershaw, Kevin Ride, and Mike Brienesse for their August 2008 review of the project and recommendations for future directions.

\section{References}

Aubin, I., S. Gachet, C. Messier and A. Bouchard. 2007. How resilient are northern hardwood forests to human disturbance? Écoscience 14 (2): 259-271.

Aubin, I., O. Deshaies, F. Cardou and L. Sirois. 2014. Management legacy in the understory of North American mixed boreal regenerating stands. Forest Ecol. Manag. 320: 129-137.

Aubin, I., M.-H. Ouellette, P. Legendre, C. Messier and A. Bouchard. 2009. Comparison of two plant functional approaches to evaluate natural restoration along an old-field - deciduous forest chronosequence. J. Veg. Sci. 20: 185-198.

Aubin, I., C. Messier, S. Gachet, K. Lawrence, D. McKenney, A. Arseneault, W. Bell, L. De Grandpré, B. Shipley, J.-P. Ricard and A.D. Munson. 2012. TOPIC - Traits of plants in Canada. Nat. Resour. Can. - Can. For. Serv., Sault Ste. Marie, ON.

Bakker, J.P., H. Olff, J.H. Willems and M. Zobel, 1996. Why do we need permanent plots in the study of long-term vegetation dynamics? J. Veg. Sci. 7(2): 147-156.

Basham, J.T. and Z.J.R. Morawski. 1964. Cull studies, the defects and associated Basidiomycete fungi in the heartwood of living trees in the forests of Ontario. Can. Dep. For., Ottawa, ON. Publ. 1072. 69 p. Bell, F.W. 2015. Effects of intensification of silviculture on plant diversity in northern temperate and boreal forests of Ontario, Canada. Sch. Environ. Sci., Univ. Guelph, PhD Diss. 408 p.

Bell, F.W. and S.G. Newmaster. 2002. Clear-cutting and conifer release alternatives affect floral richness, abundance and diversity. Part I: Seed bearing plants. Can. J. For. Res. 32: 1180-1191

Bell, F.W., J. Dacosta and G.R. Larocque. 2016. Considering forest biodiversity indicators within a pressures, state, benefits and response framework. pp. 337-359. In: Larocque, G.R. (ed.). Ecological Forest Management Handbook. CRC Press, Taylor \& Francis Group, New York, NY.

Bell, F.W., M. Shaw, J. Dacosta and S.G. Newmaster. 2017. The NEBIE plot network: Background and Experimental design. Forest. Chron. (in press, this issue).

Bell, F.W., S. Hunt, J. Dacosta, M. Sharma, G.R. Larocque, J.A. Winters and S.G. Newmaster. 2014. Effects of silviculture intensity on plant diversity response patterns in young managed northern temperate and boreal forests. Ecoscience 21(3-4): 327-33. DOI: $10.2980 / 21-(3-4)-3710$
Bell, F. W., E.G. Lamb, M. Sharma, S. Hunt, M. Anand, J. Dacosta and S.G. Newmaster. 2016. Relative influence of climate, soils, and disturbance on plant species richness in northern temperate and boreal forests. Forest Ecol. Manag. 381: 93-105.

Bell, F.W., J. Parton, N. Stocker, D. Joyce, D. Reid, M. Wester, A. Stinson, G. Kayahara and B. Towill. 2008. Developing a silvicultural framework and definitions for use in forest management planning and practice. Forest. Chron. 84: 678-693.

Biswas, S.R. and A.U. Mallik. 2010. Disturbance effects on species diversity and functional diversity in riparian and upland plant communities. Ecology 91: 28-35.

Bossel, H. 1996. TREEDYN3 forest simulation model. Ecol. Model. 90(3): 187-227.

Bruemmer, G. 2008. The Forestry Research Partnership: Developing the partnership. Forest. Chron. 84(5): 648-652.

Bunnell, F.L. 2008. Indicators for sustaining biodiversity in Canada's most controversial forest type - Coastal temperate rainforest. Ecol. Indic. 8: 149-157.

Burger, J.A. 2002. Soil and long-term site productivity values. pp. 165-189. In: Richardon, J., R Björheden, P. Hakkila, A.T. Lowe, C.T. Smith (eds). Bioenergy from Sustainable Forestry: Guiding Principles and Practice. Kluwer Academic Pub. Boston, USA.

Catford, J.A., C.C. Daehler, H.T. Murphy, A.W. Sheppard, B.D. Hardesty, D.A. Westcott, M. Rejmanek, P.J. Bellingham, J. Pergl, C.C. Horvitz and P.E. Hulme. 2012. The intermediate disturbance hypothesis and plant invasions: Implications for species richness and management. Persp. Plant Ecol. Evol. System. 14, 231-241.

Crites, S. and M.R.T. Dale. 1998. Diversity and abundance of bryophytes, lichens, and fungi in relation to woody substrate and successional stage in aspen mixedwood boreal forests. Can. J. Bot. 76(4): 641-651.

Dechene, A.D. and C.M. Buddle. 2010. Decomposing logs increase oribatid mite assemblage diversity in mixedwood boreal forest. Biodiv. Conserv. 19: 237-256.

DEPI. 2014. [Department of Environment and Primary Industries]. Victoria's State of the Forests Report 2013. Department of Environment and Primary Industries, Victoria, Australia.

Drapeau, P., A. Nappi, L. Imbeau and M. Saint-Germain. 2009. Standing deadwood for keystone bird species in the eastern boreal forest: managing for snag dynamics. Forest. Chron. 85(2): 227-234. Duvall, M.D. and D.F. Grigal. 1999. Effects of timber harvesting on coarse woody debris in red pine forests across the Great Lake States, U.S.A. Can. J. For. Res. 29: 1926-1934.

Gower, S.T. 2003. Patterns and mechanisms of the forest carbon cycle. Annu. Rev. Environ. Resour. 28: 169-204.

Harmon, M.E. and J. Sexton. 1996. Guidelines for measurements of woody detritus in forest ecosystems. University of Washington, Seattle, WA. U.S. LTER Network Office Publ. No. 2073 p.

Hayden, J., J. Kerley, D. Carr, T. Kenedi and J. Hallarn. 1995. Ontario forest growth and yield program: field manual for establishing and measuring permanent sample plots. Ont. Min. Nat. Resour., Ont. For. Res. Inst., Sault Ste. Marie, ON. 74 p. + append

Homagain, K., C.K. Shahi, N.J. Luckai, M. Leitch and F.W. Bell. 2011. Benefit-cost analysis of vegetation management alternatives: An Ontario case study. Forest. Chron. 87(2): 260-273.

Honer, T.G, M.F. Ker, and L.S. Alemdag. 1983. Metric timber tables for commercial tree species of central and eastern Canada. Can. For. Serv., Marit. For. Res. Cent. Inf. Rep. M-X-140.

Houdet, J., B. Bellini and M. Barra. 2014. La biodiversité comme enjeu stratégique pour l'entreprise. L'indicateur d'interdépendance de l'entreprise à la biodiversité. In: Les indicateurs de biodiversité forestière C. Nivet, I. Bonhême, and J.-L. Jean-Luc Peyron, 115-122. Paris: Gip Ecofor.

Huber-Sannwald, E., M.R. Palacios, J.T.A. Moreno, M. Braasch, R.M.M. Peña, J.G. de Alba Verduzco and K.M. Santos. 2012. Navigating challenges and opportunities of land degradation and sustainable livelihood development in dryland social-ecological systems: a case study from Mexico. Phil. Trans. R. Soc. B 367: 3158-3177. 
Insley, M. 2002. A real options approach to the valuation of a forestry investment. J. Environ. Econ. Manag. 44: 471-49.

Lamb, E.G., E. Bayne, G. Holloway, J. Schieck, S. Boutin, J. Herbers and D.L. Haughland. 2009. Indices for monitoring biodiversity change: Are some more effective than others? Ecol. Indic. 9: 432-444.

Landsberg, J.J. and R.H. Waring. 1997. A generalised model of forest productivity using simplified concepts of radiation-use efficiency, carbon balance and partitioning. Forest Ecol. Manage. 95(3): 209-228.

Lavorel, S. and E. Garnier. 2002. Predicting changes in community composition and ecosystem functioning from plants traits: revisting the Holy Grail. Funct. Ecol. 16: 545-556.

Lavorel, S., B. Touzard, J.-D. Lebreton and B. Clément. 1998. Identifying functional groups for response to disturbance in an abandoned pasture. Acta Oecol. 19: 227-240.

Lieffers, V.J., K.J. Stadt and Z. Feng. 2007. Free-to-grow regeneration standards are poorly linked to growth of spruce in boreal mixedwoods. Forest. Chron. 83(6): 818-824.

Lindenmayer, D.B. and J.F. Franklin. 1997. Managing stand structure as part of ecologically sustainable forest management in Australian mountain ash forests. Conserv. Biol. 11: 1053-1068.

Lowe, J., D. Pothier, J.L. Savard, G. Rompre and M. Bouchard. 2011. Snag characteristics and cavity-nesting birds in the unmanaged post-fire north-eastern Canadian boreal forest. Silv. Fenn. 45(1): 55-67.

Mabee, W.E., J. Mirck and R. Chandra. 2011. Energy from forest biomass in Ontario: Getting beyond the promise. Forest. Chron. 87: 61-70.

Malouin, C., G.R. Larocque, M. Doyle, F.W. Bell, J. Dacosta and K. Liss. 2016. Considerations of ecosystem services in ecological forest management. pp. 107-138. In: Larocque, G.R. (ed.). Ecological Forest Management Handbook. CRC Press, Taylor \& Francis Group, New York, NY.

McLaughlin, J.A. 2008. Abiotic and biotic factors associated with pocket mortality of red pine (Pinus resinosa AIT) in southern Ontario. University of Guelph Faculty of Graduate Studies, Univ. Guelph, Guelph, ON. PhD Thesis, 361 p.

MEA. 2005. [Millenium Ecosystem Assessment]. Ecosystems and Human Well-Being: Synthesis. Island Press, Washington. 155 p.

Montreal Process Working Group. 2009. Montréal Process Criteria and Indicators for the

Conservation and Sustainable Management of Temperate and Boreal Forests, Technical notes on the implementation of the Montréal Process Criteria and Indicators, Criteria 1-7. Third Edition, June 2009, Revised July 2014. <http://www.montrealprocess.org/ documents/publications/techreports/MontrealProcessTechnicalNotes3rdEditionRevisedJuly2014.pdf> Accessed April 8, 2016.

Newmaster, S.G. and F.W. Bell. 2002. The effects of silvicultural disturbances on cryptogam diversity in the boreal-mixedwood forest. Can. J. For. Res. 32: 38-51.

Newmaster, S.G., A. Lehela, M.J. Oldham, P.W.C. Uhlig and S. McMuray. 1998. Ontario Plant List. Ont. For. Res. Inst., Ont. Min. Nat. Resour., Sault Ste. Marie, ON. For. Res. Inf. Pap. No. 123. 550 p. + append.

Noland, T., L. Rich and M.S. Packalen. 2011. Establishing a sustainable harvest for Canada yew (Taxus canadensis Marsh.) in Ontario. Forest. Chron. 87(4): 529-536.

OMNR. 1994. [Ontario Ministry of Natural Resources]. Policy framework for sustainable forests. Ont. Min. Nat. Resour., For. Manage. Br., Sault Ste. Marie, ON.

OMNR. 2001. Forest management guide for natural disturbance pattern emulation, Version 3.1. Ont. Min. Nat. Resour., Toronto, ON. $40 \mathrm{p}$.

OMNR. 2007. Scaling manual, $3^{\text {rd }}$ ed. Ont. Min. Nat. Resour., Toronto, ON. 139 p.
OMNR. 2009a. Growth and yield program PSP and PGP reference manual, 2009 field season. Unpublished report.

OMNR. 2009b. Field guide to the substrates of Ontario. Operational Draft (April 27th, 2009). Ecological Land Classification Working Group, Ont. Min. Nat. Resour., Sault Ste. Marie ON. 76 p.

OMNR. 2011. Our Sustainable Future: A Renewed Call to Action Ministry of Natural Resources Strategic Directions. Toronto, ON. 24 p. OMNR. 2012. State of Ontario's Forests. Toronto: Queen's Printer for Ontario. 73 p.

Parton, W.J., J.M.O. Scurlock, D.S. Ojima, T.G. Gilmanov, R.J. Scholes, D.S. Schimel, T. Kirchner, J-C. Menaut, T. Seastedt, E.G. Moya, A. Kamnalrut and J.I. Kingyamorio. 1993. Observations and modeling of biomass and soil organic matter dynamics for the grassland biome worldwide. Glob. Biogeochem. Cycle 7(4): 785-809.

Peng, C., J. Liu, Q. Dang, M.J. Apps and H. Jiang. 2002. TRIPLEX: a generic hybrid model for predicting forest growth and carbon and nitrogen dynamics. Ecol. Model. 153(1-2): 109-130.

Petriccione, B., C. Cindolo, C. Cocciufa, S. Ferlazzo and G. Parisi. 2007. Development and harmonization of a Forest Status Indicator (FSI). Technical Report of SEBI 2010 special ad hoc project (Italian Forest Service, CONECOFOR Board). European Community Biodiversity Clearing House Mechanism, EEA, Copenhagen. 50 p. http://biodiversity-chm.eea.europa.eu/news/news266459

Pidgen, K. and A.U. Mallik, 2013. Ecology of compounding disturbances: The effects of prescribed burning after clearcutting. Ecosystems 16: 170-181.

Plonski, W.L. 1956. Normal yield tables for black spruce, jack pine, aspen and white birch in northern Ontario. Ont. Dep. Lands For., Timber Manage. Dir., Toronto, Ont. Rep. No. 24. 40 p.

Puddister, D., S.W.J. Dominy, J.A. Baker, D.M. Morris, J. Maure, J.A. Rice, T.A. Jones, I. Majumdar, P. Hazlett, B.D. Titus, R.L. Fleming and S. Wetzel. 2011. Opportunities and challenges for Ontario's forest bioeconomy. Forest. Chron. 87(4): 468-477.

Rajora, O.P. and S.A. Pluhar. 2003. Genetic diversity impacts of forest fires, forest harvesting, and alternative reforestation practices in black spruce (Picea mariana).Theor. Appl. Genet.106(7): 1203-1212.

Sharma, M., F.W. Bell, R.G. White, A. Morneault and W.T. Towill. 2010. Seedling size and woody competition most important predictors of growth following free-to-grow assessments in four boreal forest plantations. Forest. Chron. 86(2): 213-224.

Sharma, M., J. Parton, M. Woods, P. Newton, M. Penner, J. Wang, A. Stinson and F.W. Bell. 2008. Ontario's forest growth and yield modelling program: Advances resulting from the Forestry Research Partnership. Forest. Chron. 84(5): 694-703.

Smith, D.M., B.C. Larson, M.J. Kelty and P.M.S. Ashton. 1997. The Practice of Silviculture Applied Forest Ecology. $9^{\text {th }}$ Ed. John Wiley \& Sons, Inc., New York, NY.

Spies, T.A. 1998. Forest structure: A key to the ecosystem. In: Trofymow, J.A. and MacKinnon, A. (eds). Proceedings of a workshop on Structure, Process, and Diversity in Successional Forests of Coastal British Columbia, February 17-19, 1998, Victoria, British Columbia. Northwest Sci. 72 (special issue No. 2): 34-39.

Statutes of Ontario. 1994. Crown Forest Sustainability Act, 1994, S.O. 1994 , c. 25

Thompson, I.D., M.R. Guariguata, K. Okabe, C. Bahamondez, R. Nasi, V. Heymell, and C. Sabogal. 2013. An operational framework for defining and monitoring forest degradation. Ecology and Society 18 (2): 20 .

Tilman, D. 2001. Functional diversity. In: Levin, S.A. (ed.) Encyclopedia of Biodiversity. Academic Press, San Diego, CA, pp. 109-120. UNCED. 1992. [United Nations Conference on Environment and Development]. Agenda 21, Rio Declaration, Forest Principles. New York, NY., United Nations. 
USDA. 2011. [United States Department of Agriculture Forest Service]. National report on sustainable forests, 2010. FS-979. Washington, DC: U.S Dept. Agric., For. Serv., Washington Office. 212 p. Violle, C., M.-L. Navas, D. Vile, E. Kazakou, C. Fortunel, I. Hummel and E. Garnier. 2007. Let the concept of trait be functional! Oikos 116: 882-892.

Wang, S. and H.Y.H. Chen. 2010. Diversity of northern plantations peaks at intermediate management intensity. For. Ecol. Manage. 259: 360-366.

Wang, W., J. Xiao, S.V. Ollinger, A.R. Desai, J. Chen and A. Noormets. 2012. Quantifying the effects of climate change and harvesting on carbon dynamics of boreal aspen and jack pine forests using the TRIPLEX-Management model. Forest. Ecol. Manag. 281: $152-162$.

Wang, W., C. Peng, S.Y. Zhang, X. Zhou, G.R. Larocque, D.D. Kneeshaw and X. Lei. 2011. Development of TRIPLEX-Management model for simulating the response of forest growth to precommercial thinning. Ecol. Model. 222(14): 2249-2261.

Wang, W., C. Peng, D.D. Kneeshaw, G.R. Larocque, X. Lei, Q. $\mathrm{Zhu}, \mathrm{X}$. Song and Q. Tong. 2013. Modeling the effects of varied forest management regimes on carbon dynamics in jack pine stands under climate change. Can. J. For. Res. 43(5): 469-479.
Whitney, R.D. 1995. Root-rotting fungi in white spruce, black spruce, and balsam fir in northern Ontario. Can. J. For. Res. 25: 1209-1230.

Yang, R.C. and F.C. Yeh. 1992. Genetic consequences of in situ and ex situ conservation of forest trees. Forest. Chron. 68: 720-729.

Zakrzewski, W.T. 2001. TCM/PAM system: Support tool for timber surveys. User's manual. Ont. Min. Nat.Resour., Ont. For.Res. Inst., Sault Ste. Marie, ON. Unpub. rep.

Zhou, X., C. Peng and Q. Dang. 2004. Assessing the generality and accuracy of the TRIPLEX model using in situ data of boreal forests in central Canada. Environ. Model. Softw. 19(1): 35-46.

Zhou, X., C. Peng, Q. Dang, J. Chen and S. Parton. 2005. Predicting forest growth and yield in northeastern Ontario using the process-based model of TRIPLEX1.0. Can. J. For. Res. 35(9): $2268-2280$. 